\title{
The Late Carboniferous deeply eroded Tharandt Forest caldera-Niederbobritzsch granite complex: a post-Variscan long-lived magmatic system in central Europe
}

\author{
Christoph Breitkreuz $^{1}$ (D) $\cdot$ Alexandra Käßner ${ }^{2} \cdot$ Marion Tichomirowa $^{2} \cdot$ Manuel Lapp $^{3} \cdot$ Shan Huang $^{4} \cdot$ Klaus Stanek $^{1}$
}

Received: 10 September 2020 / Accepted: 26 February 2021 / Published online: 8 April 2021

(c) The Author(s) 2021

\begin{abstract}
Samples and documentation of outcrops and drillings, facies analysis, whole rock geochemistry and radiometric ages have been employed to re-evaluate the Late Carboniferous Tharandt Forest caldera (TFC) and the co-genetic Niederbobritzsch granite (NBG) in the eastern Erzgebirge near Dresden, Germany. The c. $52 \mathrm{~km}^{2}$ TFC harbours strongly welded ignimbrites with a preserved minimum thickness of $550 \mathrm{~m}$. Composition of initial fallout tephra at the base of the TFC fill, comprising lithics of rhyolitic and basic lava, and of silica-rich pyroclastic rocks, suggests a bimodal volcanic activity in the area prior to the climactic TFC eruption. The lower part of the TFC fill comprises quartz-poor ignimbrites, overlain by quartz-rich ignimbrites, apparently without a depositional break. Landslides originating from the collapse collar of the caldera plunged into the still hot TFC fill producing monolithic gneiss mesobreccia with clasts $\leq 1 \mathrm{~m}$ in a pyroclastic matrix. Aphanitic and porphyritic rhyolitic magma formed ring- and radial dykes, and subvolcanic bodies in the centre of TFC. Whole rock geochemical data indicate a high silica (most samples have $>73 \mathrm{wt} \% \mathrm{SiO}_{2}$ ) rhyolitic composition of the TFC magma, and a similar granodiorite-granitic composition for the NBG. Based on drillings and caldera extent, a minimum volume of $22 \mathrm{~km}^{3}$ of TFC fill is preserved, the original fill is assumed at about $33 \mathrm{~km}^{3}$. This estimate translates into a denudation of at least $\mathrm{c}$. $210 \mathrm{~m}$ during Late Paleozoic to pre-Cenomanian. Telescopic subsidence of the TFC took place in two, perhaps three stages. A possible TFC outflow facies has been completely eroded and distal TFC tuff has not been recognized in neighboring basins. New CA-ID-TIMS measurements on two TFC samples gave mean zircon ages of $313.4 \pm 0.4 \mathrm{Ma}$ and $311.9 \pm 0.4 \mathrm{Ma}$; two samples from NBG resulted in 318.2 $\pm 0.5 \mathrm{Ma}$ and 319.5 $\pm 0.4 \mathrm{Ma}$. In addition, for one sample of the ring dyke an age of ca. $314.5 \pm 0.5 \mathrm{Ma}$ has been obtained. These ages, together with field relations, allow for a model of a long-standing evolution of an upper crustal magmatic system ( $5 \mathrm{Ma}$ ?), where pulses of magmatic injection and crustal doming alternate with magmatic quietness and erosion. Together with the Altenberg-Teplice Volcanic Complex, located some $10 \mathrm{~km}$ to the southeast, the TFC-NBG Complex represents an early post-Variscan magmatic activity in central Europe.
\end{abstract}

Keywords Single phase caldera evolution $\cdot$ Caldera wall landslides $\cdot$ Freiberg gneiss dome $\cdot$ CA-ID-TIMS zircon dating

\section{Introduction}

Christoph Breitkreuz

cbreit@geo.tu-freiberg.de

1 Institut für Geologie, TU Bergakademie Freiberg, Freiberg, Germany

2 Institut für Mineralogie, TU Bergakademie Freiberg, Freiberg, Germany

3 Landesamt für Umwelt, Landwirtschaft und Geologie, Freiberg, Germany

4 Institut für Geotechnik, TU Bergakademie Freiberg, Freiberg, Germany
At the end of Variscan orogeny, widespread and intense magmatic activity occurred throughout central Europe. Permian-Carboniferous magmatism was dominated in many regions by large calderas and subvolcanic complexes (Röllig 1976; Benek et al. 1996; Awdankiewicz et al. 2004; Breitkreuz et al. 2007; Geißler et al. 2008; Hoffmann et al. 2013; Schmiedel et al. 2015). Some of the late- to post-Variscan volcanic systems display large volumes of crystal-rich ignimbrites qualifying these as supereruptions (Willcock et al. 2013; Repstock et al. 2018). 
Intense magmatism took place in both, western and eastern parts of the Erzgebirge/Krušné hory, located at the German-Czech border region. The metamorphic basement comprises a Variscan nappe stack with different $P-T$ histories (Rötzler et al. 1998; Schmädicke et al. 1995; Willner et al.
1997). Mainly plutonic rocks crop out in the Western Erzgebirge while both plutonic and volcanic rocks occur in the Eastern Erzgebirge. There, the magmatic activity is mainly confined along a NNW-SSE trending zone (Fig. 1). These are, from south to north, the Altenberg-Teplice Volcanic

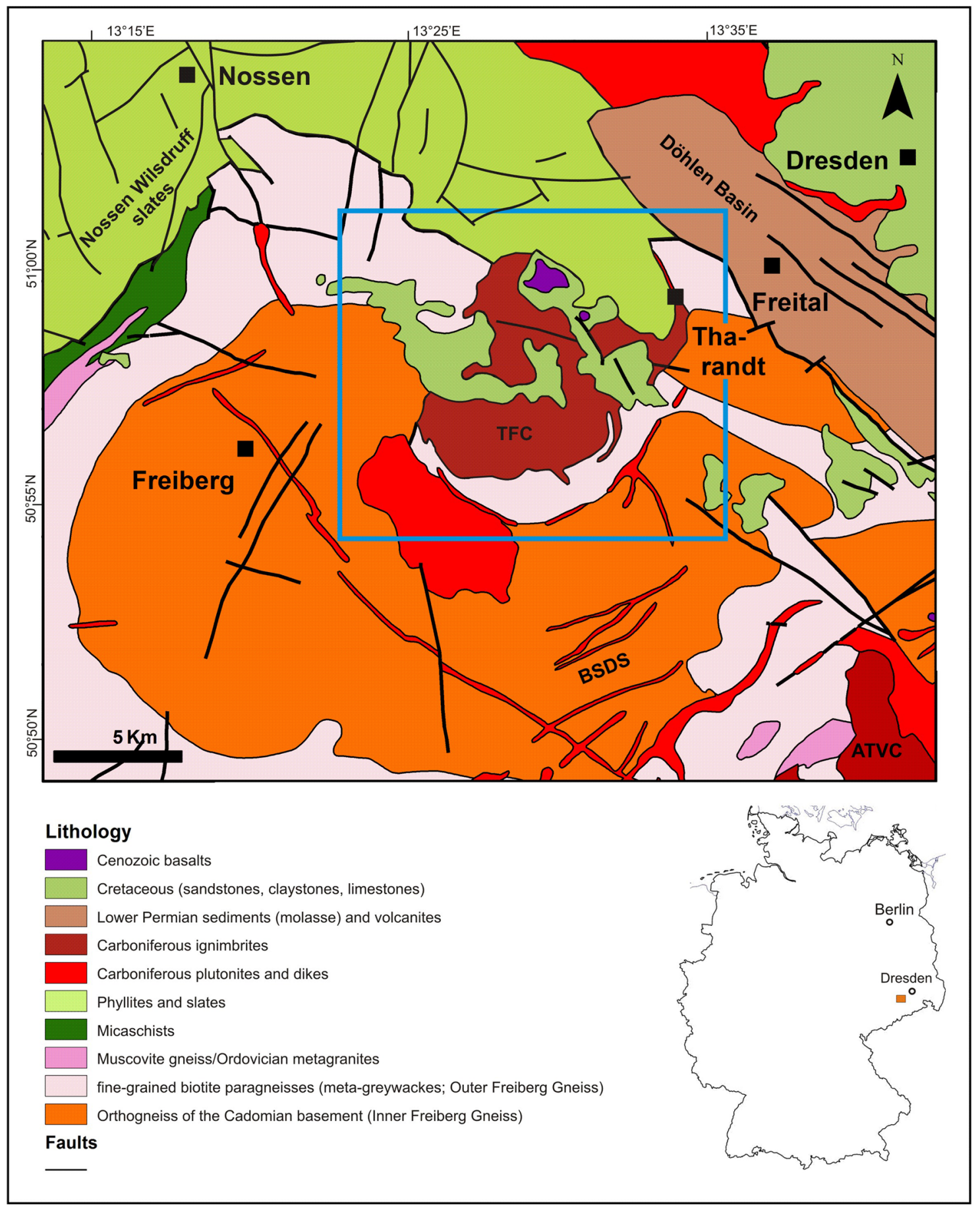

Fig. 1 Geological sketch map of the eastern Erzgebirge showing the Tharandt Forest caldera (TFC), the Niederbobritzsch granite (NBG), the Berggießhübel-Sayda dyke swarm (BSDS), and the Altenberg-
Teplice Volcanic Complex (ATVC); blue box shows location of Figs. 2, 4 and 5 and Appendix Figures B (modified after Hoth et al. 1992) 
Complex (ATVC; Breiter et al. 2001; Hoffmann et al. 2013; Walther et al. 2016; Casas García et al. 2019; Tomek et al. 2019, 2021), the NE-SW-trending Berggießhübel-Sayda Dyke Swarm (BSDS; Wetzel 1984; Winter et al. 2008) and the Tharandt Forest caldera-Niederbobritzsch granite (TFC-NBG). While the elongated shape of the ATVC reflects an evolution under a regional transtensional regime (Casas García et al. 2019), the TFC has the rounded shape of a classic piston caldera surrounded by a dome-like structure of the hosting gneiss (Freiberg gneiss dome). Gneiss domes are a common feature of the entire Erzgebirge (Willner et al. 2000).

Piston calderas are typically related to magma reservoirs at shallow depth (Walker 1984; Cole et al. 2005). Deep erosion, as assumed for the TFC, may reveal stepped subsidence accommodated along ring faults, often associated with cone sheet dykes (Kennedy and Stix 2007; Kennedy et al. 2012; Galetto et al. 2017). Lipman (1976) reported on lithic breccias intermixed with ignimbrites, similar to the features present in the TFC, which are exposed in deeply eroded calderas in the western San Juan Mountains (CO, USA). They originate from syn-eruptive rock fall and landslides (sensu lato) at the caldera walls.

The geometry of many caldera systems is strongly influenced by the dynamics in the upper crustal magma reservoirs and by (sub-) volcanic pulses; the latter may lead to resurgence or regional doming (Kennedy et al. 2012; Gregg et al. 2012). Henry et al. (1997) studied the Solitario lacco-caldera complex in southwestern Texas where a $16 \mathrm{~km}$ structural dome formed by the emplacement of a laccolith. On its summit, a c. 6-km-wide caldera erupted. A similar scenario will be discussed here for the TFC related to the NBG. Furthermore, as we shall display for the TFC-NBG complex, many sub recent upper crustal magmatic centres, like Yellowstone, Jemez Mtns. and Cerro Galan, experienced a longstanding history with complex crustal magma reservoirs and nested calderas (Folkes et al. 2011; Kelley et al. 2013; Myers et al. 2019).

So far, publications on TFC were restricted to information from outcrop features and samples (Benek 1980). Alexowsky et al. (2012) issued a revised geological map covering the eastern part of TFC, presenting some data from drillings (see also Stanek and Renno 2001). In the late 1960-early 1970s, the SDAG Wismut (since 1991: Wismut GmbH) carried out a detailed exploration project on the TFC, including intensive drilling as deep as $371.4 \mathrm{~m}$ (Kalmykow et al. 1971). Based on these exploration drillings (cores and documentation) and outcrops, we present a detailed re-evaluation of the lithofacies, geometry and evolution of the TFC. New whole rock geochemical data and $\mathrm{U} / \mathrm{Pb}$ ages on zircon from TFC and the adjoining NBG are presented, contributing to better constrain the style and timing of intrusive and volcanic activity in the Eastern Erzgebirge.

\section{Geological setting and previous studies}

The metamorphic units of the Erzgebirge show nume-rous large structural domes (e.g., Freiberg dome, Reitzenhain-Catherine dome) with a few located above Variscan plutonic complexes (Freiberg dome, Schwarzenberg dome; Willner et al. 2000). The TFC and the southwesterly adjoined Niederbobritzsch granite (NBG) are hosted by the Freiberg gneiss dome (diameter c. 40 km; "Freiberger Gneiskuppel") that displays a concentric alignment of the D2 foliation around TFC and NBG (Willner et al. 2000). While the outcrop of NBG is positioned in the centre of the dome, the TFC is somewhat displaced towards the northeast (Fig. 1). Outcrops in the core of the dome display coarse-grained biotite gneiss (orthogneiss called Inner Freiberg Gneiss, IFG, Tichomirowa et al. 2001). It is part of the medium pressure-medium temperature unit (MP-MT; Kröner et al. 1995; Rötzler 1995) and has a protolith age of 550-540 Ma (Kröner et al. 1995; Tichomirowa et al. 2001, 2012). They are enclosed by finegrained grey paragneiss (Outer Freiberg Gneiss-OFG, Fig. 1) interpreted as meta-greywackes (with the youngest zircon age population at ca. $575 \mathrm{Ma}$; Tichomirowa et al. 2001, 2012) belonging to the high pressure-high temperature unit (HP-HT; Schmädicke et al. 1995; Willner et al. 1997; Rötzler et al. 1998). The OFG contains lenses of amphibolites and small eclogite bodies (Tichomirowa et al. 2001, 2012).

Granites of the Erzgebirge/Krušné hory are typically divided into earlier low-F biotite granites and later highly evolved Li-F-rich two-mica granites (Förster 1998). These two groups were also named the "older intrusive complex" (OIC) and the "younger intrusive complex" (YIC; e.g., Lange et al. 1972; Štemprok 1986; Tischendorf et al. 1987). In addition, some authors distinguish "transitional granites" corresponding to low/medium-F two-mica monzo- and syenogranites (Štemprok 1986). The older I/S type granites have Upper Mississippian to Lower Pennsylvanian ages (like for instance the southern Eibenstock-Nejdek pluton: c. 322 Ma, Kováříková et al. 2007; Aue-Schwarzenberg: ca. 323-322 Ma, Tichomirowa et al. 2019; Bergen and Kirchberg: ca. 320-318 Ma, Tichomirowa et al. 2019) and are probably coeval with the ATVC and the co-genetic Flaje pluton (325-317 Ma according to Casas García et al. 2019; Tomek et al. 2021), and with the TFC-NBG.

The TFC is a deeply eroded caldera structure, as, in principle, already interpreted by Moesta (1928); the caldera character has been clarified later by a detailed study of Benek (1980). The content of phenocrysts (qtz, fsp) ranges from $13 \%$ for the "normal rhyolite" (here named quartz-poor ignimbrite, QPI) up to $33 \%$ for the quartz-phyric rhyolite (here QRI; Schulze 1963). Benek and Harff (1981) presented data on the mean size of crystals (qtz, fsp), lithics and fiamme, together with a rough estimate of the modal distribution. The voluminous QPI is overlain by QRI, and there are transitions between the two 
types (Figs. 2, 3). The 3d orientation and abundance of fiamme, and the distribution, size and types of lithics in QPI and QRI were measured in detail by Benek (1980; Fig. 4 and AppendixFig. B).
The TFC exposes welded ignimbrites in a c. $52 \mathrm{~km}^{2}$ area. Much of the TFC is encircled by orthogneiss (IFG) and fine grained paragneiss (OFG). Towards the northeast, early Paleozoic phyllites and slates (PPS) of the Nossen Wilsdruff slate mountains crop out overriding

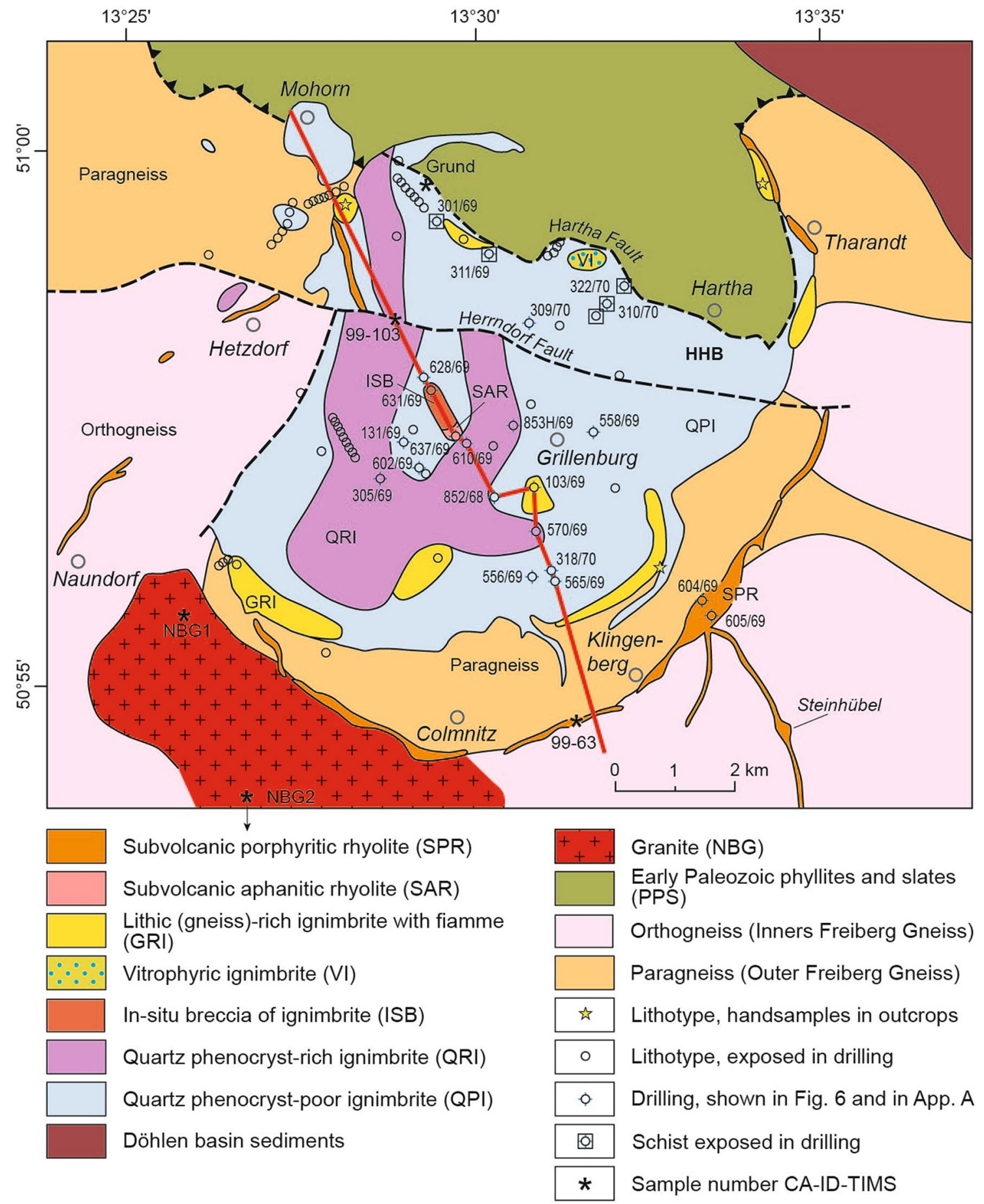

Fig. 2 Geological sketch map of the TFC-NBG complex based on outcrop and drilling information; Cretaceous and Cenozoic cover (including Cenozoic volcanics) removed (modified after Kalmykow et al. 1971; Benek 1980; Alexowsky et al. 2012); HHB HerrndorfHartha Block; position of profile (Fig. 3) indicated by red line 


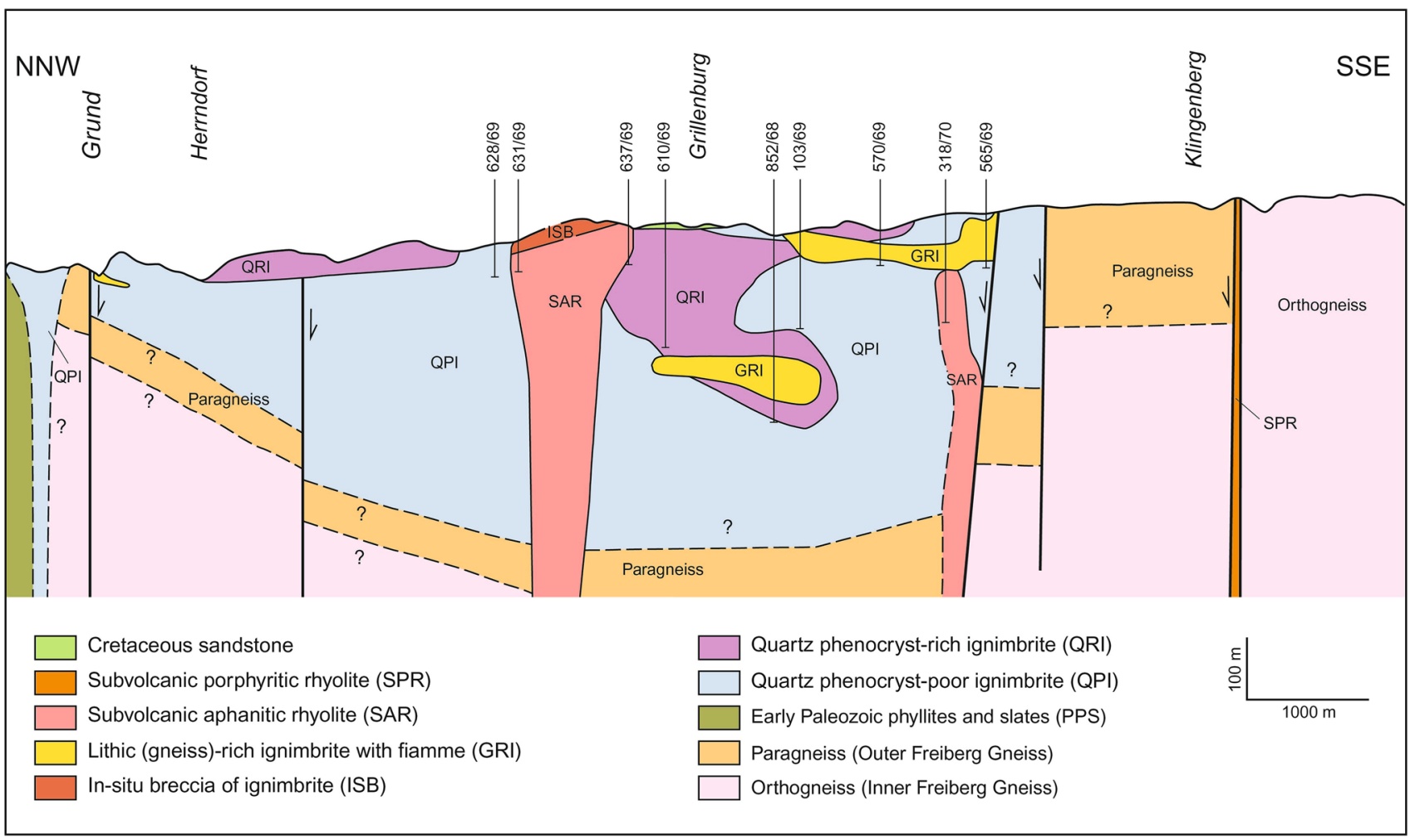

Fig. 3 NNW-SSE-profile through the TFC, based on outcrop and drilling data, for position see Fig. 2

IFG along a gently dipping fault. The Hartha Fault shown in Fig. 2 is a local volcanotectonic element active during caldera subsidence which delimitates TFC ignimbrites from PPS (see below).

About half of the TFC is discordantly covered by Cretaceous sediments ( $\leq 28 \mathrm{~m}$ thick, Alexowsky et al. 2012). In the north, an Oligo-Miocene basaltic vent is located (Ascherhübel), with associated 2-km-long lava flow relict located to the northwest (Fig. 1).

Ring and radial dykes are exposed at the TFC margin. At Steinhübel, a NW-SE-striking dyke has a 250-m-wide bulge (Fig. 2; Lapp and Breitkreuz 2015). In the centre of the bulge, a welded pyroclastic domain crops out. A similar situation was described at Turmberg and Burgberg of the Berggießhübel-Sayda dyke swarm by Winter et al. (2008; Fig. 1). The pyroclastic domain at Steinhübel displays vertically NW-SE-oriented fiamme and subhorizontally oriented cooling columns (Lapp and Breitkreuz 2015).

Previous studies documented various rounded and elongated intrusions of pyroclastic and coherent material into the PPS and the gneiss surrounding TFC (Figs. 1, 2; Sauer 1887; Sauer and Beck 1891; Pietzsch 1914; Benek 1980; Stanek and Renno 2001; Alexowsky et al. 2012). Lithology and volcano-tectonic structures in one of these intrusions, the SW-NE-oriented "Grunder Spalte" (Fig. 2), has been investigated in detail by Schwab (1962).
Kalmykow et al. (1971) carried out a detailed exploration campaign on TFC and they discovered, by drilling, bodies of subvolcanic rhyolite in the central TFC. A number of deep drillings carried out by the SDAG WISMUT near Grillenburg (Fig. 2) have not penetrated completely the TFC rhyolites; among these, drilling $853 \mathrm{H} / 69$ reached down to $371 \mathrm{~m}$ (Fig. 6 and Appendix-Fig. A). For the quartz phenocryst-poor rhyolite, Benek (1980) assumed a thickness of 500-600 m inferred from the bowl-like shape of the $3 \mathrm{~d}$ orientation of pseudofluidal texture in outcrops (fiamme; Fig. 4a). For the quartz-rich rhyolite another $300 \mathrm{~m}$ in thickness is suspected. According to Förster et al. (2008), the preserved volume of the ignimbrite is $25-30 \mathrm{~km}^{3}$.

A peculiarity of the Late Carboniferous TFC is the glassy facies of the famous spherulitic pitchstone ("Kugelpechstein") of Spechtshausen (Figs. 2, 7h). The pitchstone is a densely welded lithic-rich, quartz-poor ignimbrite, related to QPI. Microcrystalline spherulites up to $15 \mathrm{~cm}$ in diameter grew around lithic fragments (Lapp and Breitkreuz 2015).

The Niederbobritzsch granite (NBG, Fig. 1) belongs to the group of late-Variscan low-F biotite monzogranites that possess transitional I- to S-type affiliation (Förster et al. 1999; Romer et al. 2014). Their low initial ${ }^{87} \mathrm{Sr} /{ }^{86} \mathrm{Sr}$-ratios (0.705-0.706) and their high $\delta^{11} \mathrm{~B}$ values (20-21\%o) point to a larger contribution of mafic material in the source compared to other low-F granites in Saxothuringia (Romer et al. 

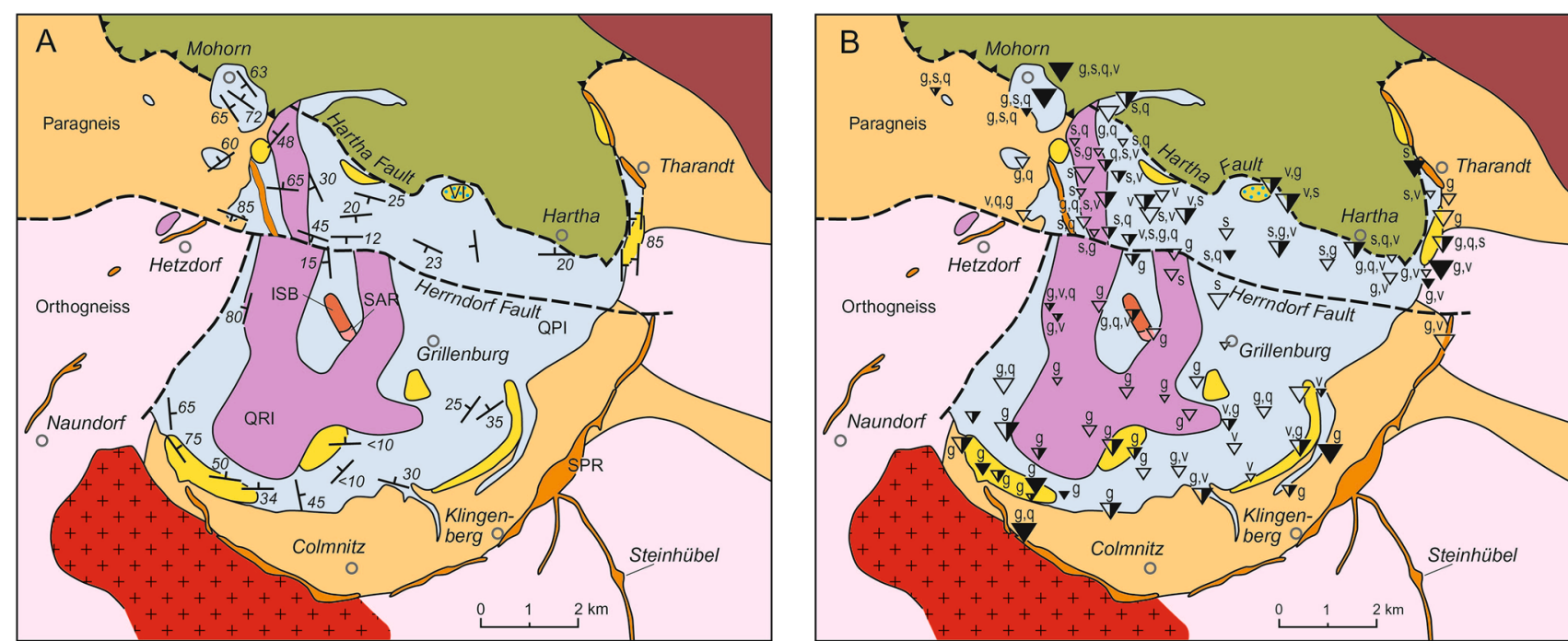

Subvolcanic porphyritic rhyolite (SPR)

Subvolcanic aphanitic rhyolite (SAR)

Lithic (gneiss)-rich ignimbrite with fiamme (GRI)

Vitrophyric ignimbrite (VI)

In-situ breccia of ignimbrite (ISB)

Quartz phenocryst-rich ignimbrite (QRI)

Quartz phenocryst-poor ignimbrite (QPI)

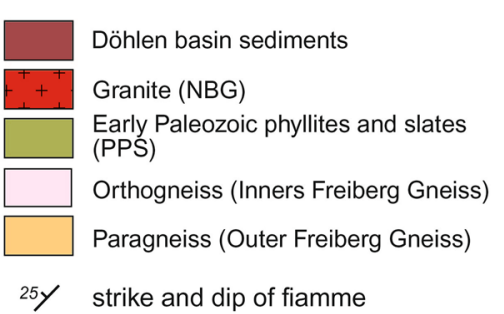

Lithies

number

$\nabla$ rare

s schist, phyllite

$\nabla$ numerous q vein quartz

$\checkmark$ volcanics

Fig. 4 a 3d orientation of fiamme in TFC ignimbrites; b distribution, type and size of lithics in TFC ignimbrites (redrawn after Benek 1980); map modified after Kalmykow et al. (1971), Benek (1980) and Alexowsky et al. (2012)

2014). It forms a multiphase pluton that consists of four mappable, texturally and compositionally distinct intrusive units (Rösler and Budzinski 1994; Förster 2000). A Pb-Pb zircon evaporation dating yielded a Late Carboniferous age (320 \pm 6 Ma; Tichomirowa 1997). Förster (1998) published an EMP age of $324 \pm 4$ Ma on monazite, xenotime and uraninite.

For the TFC, Kalmykow et al. (1971) assembled a map of the vertical magnetic field anomaly $(\Delta Z)$, based on a detailed magnetic field balance survey (Fig. 5). The map features prominent pairs of positive and negative anomalies, which, principally, may represent inductive anomalies or remanence. In northern hemisphere latitudes, the former typically is characterized by a negative anomaly positioned to the north of a positive domain. Inductive anomalies may be interpreted for the area of the Cenozoic Ascherhübel volcano and the associated lava to the northwest (Figs. 1, 5). The other anomalies in Fig. 5 are presumably related to the presence of $\mathrm{Fe}$-oxide-rich volcanic and subvolcanic units of the TFC. The faulted southern margin of the TFC is well imaged by strong anomaly pairs (further description/interpretation in the result and discussion sections). Kalmykow et al. (1971) also outlined faults assumed or confirmed by the documented magnetic patterns (Fig. 5).

\section{Methods}

For the present study, the available documentation of exploration drillings in the TFC area has been re-evaluated. In particular, deep-reaching drillings ( $>100 \mathrm{~m}$ ) have been considered for TFC lithofacies and geometry analysis. Apart from scarce outcrops, all preserved drill cores, located in the core depository of the Saxony State Survey for Agriculture, Environment and Geology (Freiberg), have been examined and sampled (see blue signatures in Fig. 6 and AppendixFig. A). Samples have been cut and one half polished. The other half was used for thin sections and, where feasible, for whole rock geochemical analysis. Sample label, e.g., 103/69-141.0, is drilling number/year-depth in meter below surface. Thin sections have been examined for qualitative petrography and volcanic facies analysis. 13 thin sections have been coloured for K-feldspar and used for modal analysis (1000 points per thin section; Table 2). With pyroclastic rocks, fiamme and phenocrysts therein have been counted as groundmass or crystals, respectively. In the same set of thin sections, maximum particle size (MPS; mean value of three largest crystals) of quartz and feldspar was measured (Table 2). 

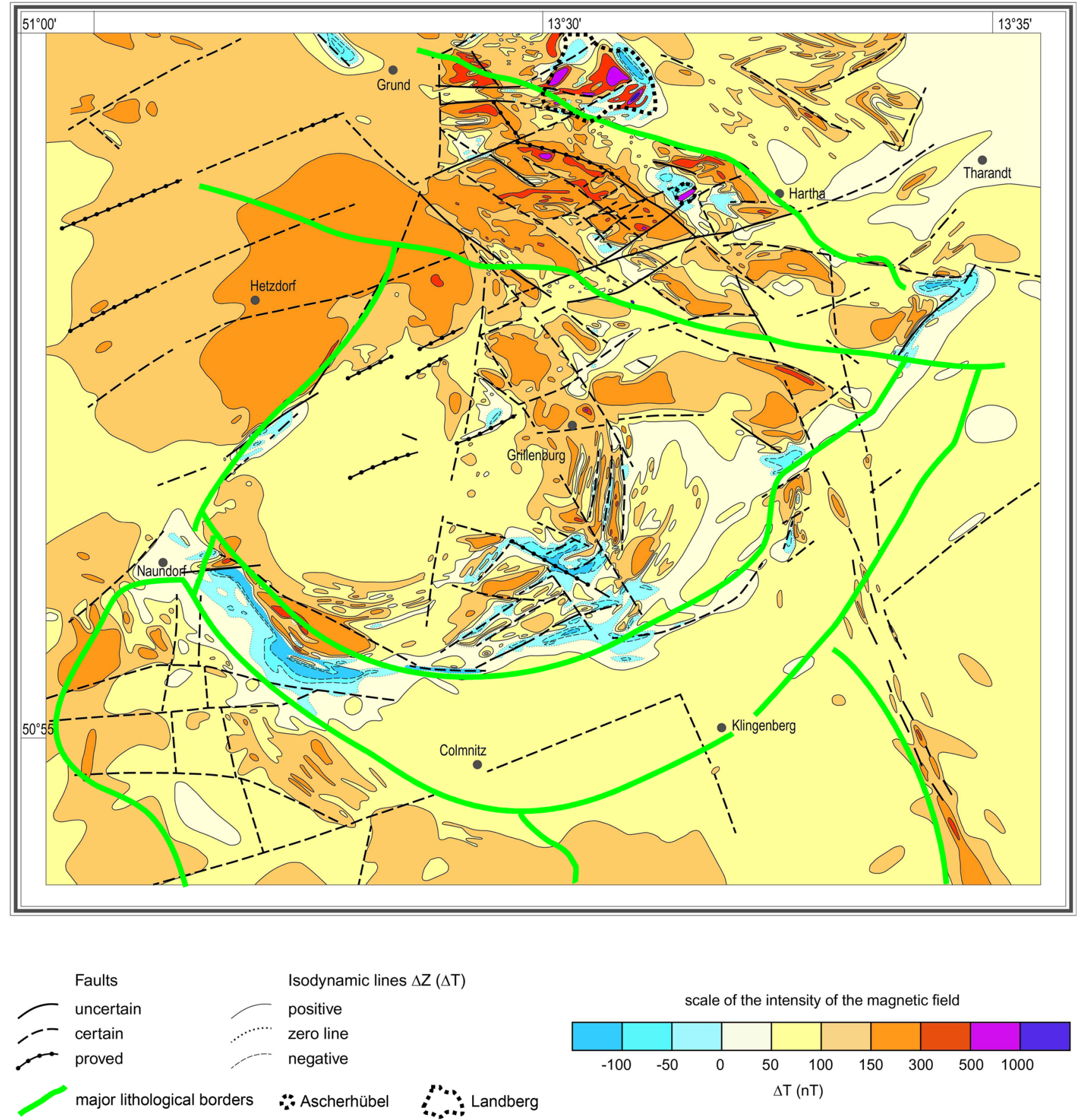

Fig. 5 Map of the magnetic anomalies and major faults of the TFC (modified after Kalmykow et al. 1971); for orientation, green lines mark the major lithological borders shown in Fig. 2; bold black dashed lines mark the location of the Cenozoic volcano and lava (Fig. 1)

All samples selected for geochemistry display only weak alteration (partial sericitisation of feldspar, presence of primary fibrous crystals in spherulites). Twenty-nine whole rock samples of drill cores have been analyzed by ALS Minerals, Loughrea, Ireland, for main and trace elements (Appendix Table A). Samples with few or absent lithics have been selected; except sample 556-/69-50.0 which has a lithic-rich, GRI lithology. Major oxides have been determined by ICP-AES and trace and rare earth elements by ICPMS methods. Whole rock geochemistry of surface samples is displayed in Appendix Table B; analysis has been carried out at ACMELAB, Vancouver (Canada; Analytical methods and detection limits for both labs in Appendix-Table C; georeference list for outcrop samples in Appendix-Table D). 
$322 / 70$
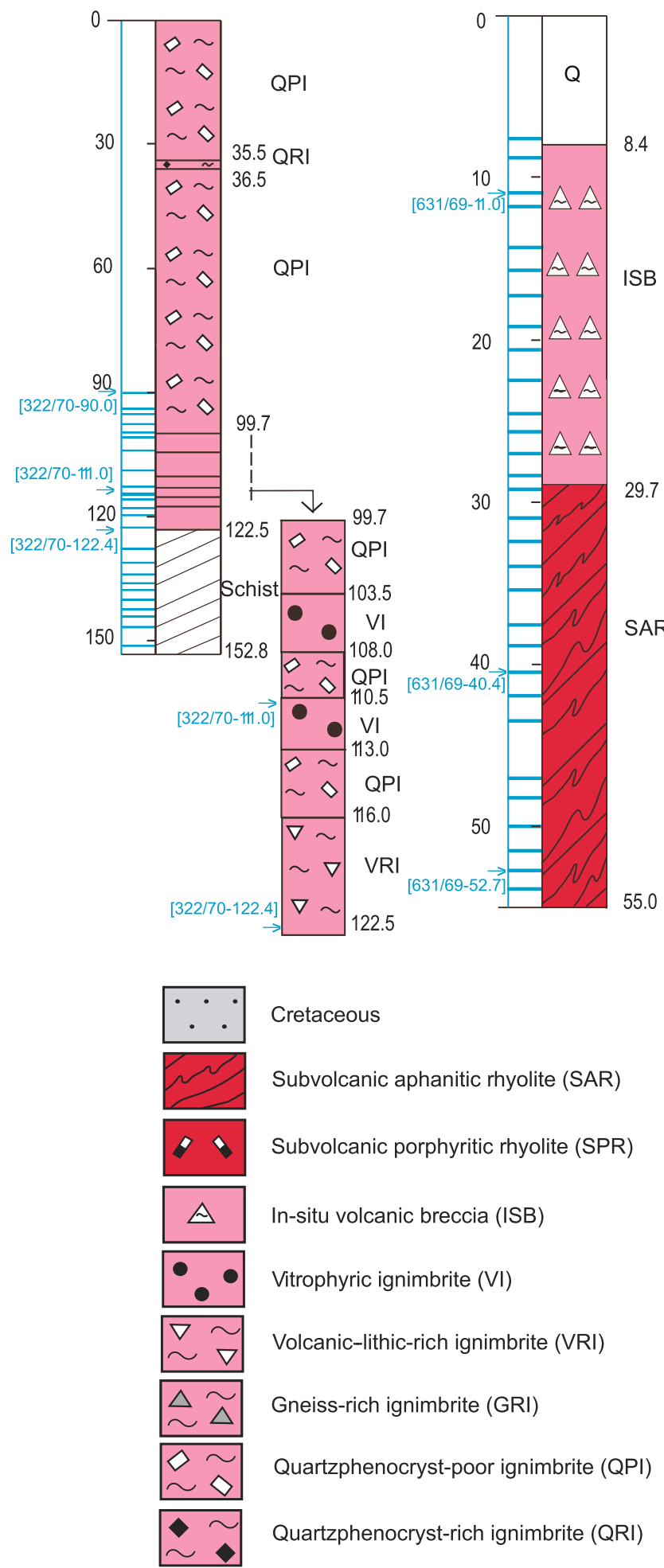

Cretaceous

Subvolcanic aphanitic rhyolite (SAR)

Subvolcanic porphyritic rhyolite (SPR)

In-situ volcanic breccia (ISB)

Vitrophyric ignimbrite (VI)

Volcanic-lithic-rich ignimbrite (VRI)

Gneiss-rich ignimbrite (GRI)

Quartzphenocryst-poor ignimbrite (QPI)

Quartzphenocryst-rich ignimbrite (QRI)
$631 / 69853 \mathrm{H} / 69$

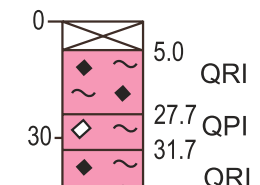

$60-$

$\sim$ QRI

$\diamond \sim 50.1_{[103 / 69-33.3]}^{30}$

$\Delta \sim$
$\sim \Delta$

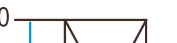

/69-38.2] $\rightarrow$

$556 / 69$

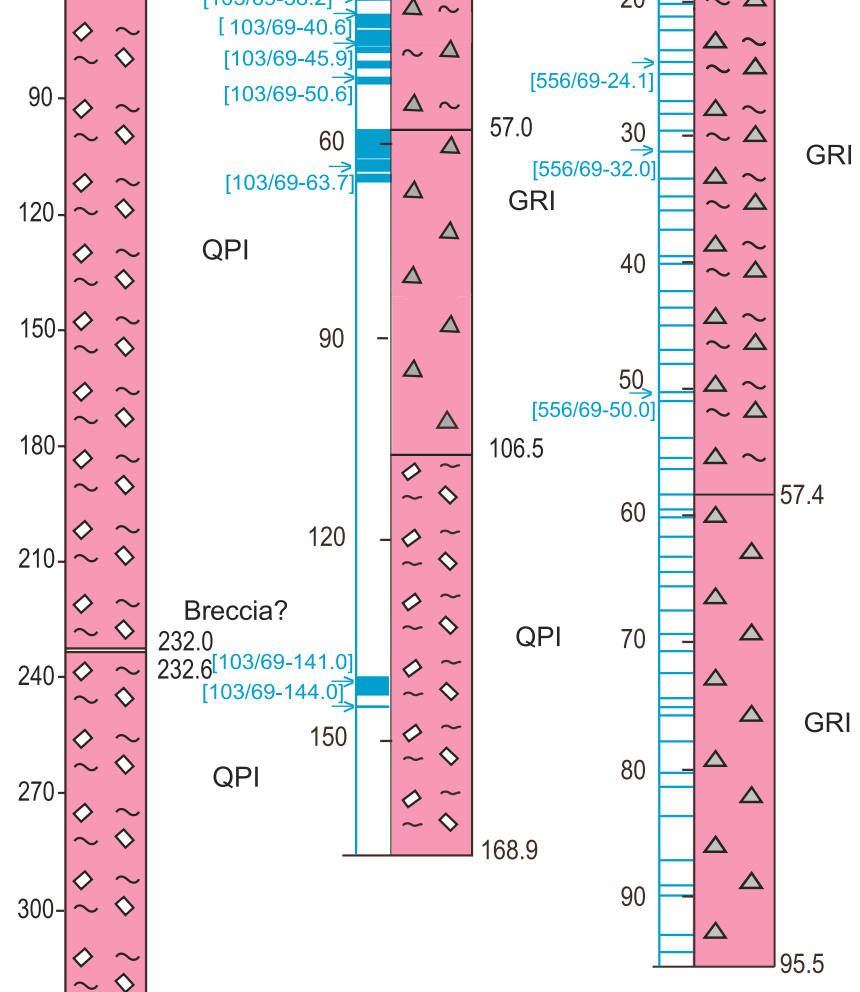

23.0

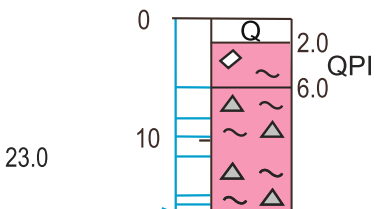

GRI

$330-$

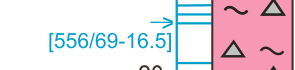

$\sim$

〜 $\triangle$

$360-$

$\diamond \sim$

$\Delta \sim \sim_{371,4}$

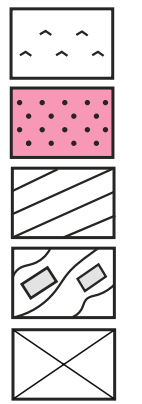

Calcareous porous tuff

Fallout

Schist

Gneiss

No core preserved

Fig. 6 Selected drilling profiles along a N-S section through the TFC, blue signature represents investigated preserved drill cores and sample location (more drilling profiles in Appendix-Fig. A, for drilling location see Fig. 2) 
From each, TFC and NBG, two samples were dated by the CA-ID-TIMS method to get a first estimate of their magmatic duration. In addition, one sample was dated from the southern ring dyke of TFC (for location see Fig. 2, data in Table 3). CA-ID-TIMS ages have been shown to be accurate and precise at a $0.1 \%$ level $( \pm 0.3-0.4 \mathrm{Ma}$ at ca. $300 \mathrm{Ma}$; Tichomirowa et al. 2019; Lützner et al. 2021). The accuracy was checked in the TIMS lab in Freiberg by dating international standards yielding $1064.6 \pm 1.3 \mathrm{Ma}$ for the standard 91500 (certified age is $1062.4 \pm 0.4 \mathrm{Ma}$ according to Wiedenbeck et al. 1995, and 1063.6 $\pm 0.3 \mathrm{Ma}$ according to Schoene et al. 2006) and 417.3 $\pm 0.6 \mathrm{Ma}$ for the standard Temora 2 (certified age is $416.8 \pm 0.3 \mathrm{Ma}$; Black et al. 2003).

Dating was performed in the TIMS lab at TU Bergakademie Freiberg (Germany). Selected zircon grains (ca. 15-30 per sample) were annealed for $72-96 \mathrm{~h}$ at $850{ }^{\circ} \mathrm{C}$ and subsequently chemically abraded with concentrated $\mathrm{HF}$ and $\mathrm{HNO}_{3}$ for $12-15 \mathrm{~h}$ at $200{ }^{\circ} \mathrm{C}$. This procedure dissolves crystal domains with strong radiation damage which are suspected to have experienced post-crystallization lead loss (Mattinson 2005). Afterwards, the acid together with dissolved zircon material was completely pipetted out and $3.5 \mathrm{~N} \mathrm{HNO}_{3}$ was added to the remaining zircon grains and fragments, and left for $30 \mathrm{~min}$. at $50{ }^{\circ} \mathrm{C}$ to remove surface lead. Several cleaning cycles with water combined with repeated ultrasonic treatment were conducted before single zircon fragments were selected for further processing.

Single zircon grains/fragments were washed with $3 \mathrm{~N}$ $\mathrm{HNO}_{3}$ and transferred into cleaned microcapsules with a small drop of this fluid and three drops of concentrated HF. Samples were spiked with $6-10 \mathrm{mg}$ of a ${ }^{205} \mathrm{~Pb}-{ }^{233} \mathrm{U}-{ }^{235} \mathrm{U}$ tracer solution (ET535 at TU Bergakademie Freiberg; Condon et al. 2015). For final dissolution, the microcapsules were placed in Parr vessels and heated to $200{ }^{\circ} \mathrm{C}$ for $48 \mathrm{~h}$, followed by drying at $130^{\circ} \mathrm{C}$ and then re-dissolution in $6 \mathrm{~N}$ $\mathrm{HCl}$ for $24 \mathrm{~h}$ at $200^{\circ} \mathrm{C}$ to transfer them into chlorides. After repeated drying, the samples were dissolved in ten drops of $3.1 \mathrm{~N} \mathrm{HNO}_{3}$ and transferred into micro-columns for column chemistry. $\mathrm{U}$ and $\mathrm{Pb}$ were separated from the rest of the sample by anion exchange chromatography using $\mathrm{HCl}$ and $\mathrm{H}_{2} \mathrm{O}$. The $\mathrm{U}$ and $\mathrm{Pb}$ containing fraction was loaded on pre-degassed rhenium filaments with a drop of silica gel and measured with a Finnigan Mass Spectrometer MAT 262 using a secondary electron multiplier (SEM).

\section{Results}

\section{Geometry and outcrop relations}

The TFC comprises a c. $10 \mathrm{~km}$ wide, sub circular area where quartz-poor- and quartz-rich ignimbrites crop out, or have been discovered by drilling-in places, below the cover of Cretaceous sediments (Figs. 1, 2, 3). Ignimbritic facies has been detected by drilling down to $371.4 \mathrm{~m}$ depth (drilling $853 \mathrm{H} / 69$, Fig. 6), however, the preserved maximum thickness of the caldera fill is not known. In the central part of the TFC, subvolcanic rhyolitic bodies have been discovered by drilling (Figs. 2, 3; Kalmykow et al. 1971). In the northeastern sector, the TFC occurs adjoined to early Paleozoic phyllites and slates (PPS) along a NW-SE-trending sharp contact (Hartha Fault, Fig. 2). Southwest of the Hartha Fault, TFC fill deposits rest on PPS basement located in less than $218 \mathrm{~m}$ depth, as detected by a number of drillings (Figs. 2, 6). This block, herewith named Herrndorf-Hartha Block (HHB), is presumably delimited to the southwest by the NW-SE-striking Herrndorf Fault (Fig. 2; Benek 1980). In the eastern and southern sectors, sub circular fault/contacts sets TFC ignimbrite and gneiss-rich breccia against OFG, in the western sector against IFG (Tichomirowa et al. 2001). The distribution of lithics in the caldera fill ignimbrites reflects the type of host rocks. While in the central and southern part of TFC, gneiss fragments dominate, in the northeast, slate fragments derived from the PPS prevail (Fig. 4b; Benek 1980).

In places, complex contact relations exist between TFC ignimbrites and host rocks: (1) in the north, near Mohorn, an ignimbritic protrusion has been mapped trending NEwards into the PPS (Schwab 1962; Benek 1980); (2) in the east, near Tharandt, a c. $2 \mathrm{~km}$ long spur of brecciated gneiss protruded northwards into the TFC ignimbrites (Fig. 2; Benek 1980); (3) at the southwestern TFC margin, fiammerich pyroclastic dykes crosscut gneiss, and nearby, lenses of gneiss-rich breccia have been mapped.

Along the NE-, E-, SE-, S- and SW-sectors an outer ring fault/dyke encircles the TFC, with a distance of up to $1500 \mathrm{~m}$ away from the inner ring fault system (Fig. 2). The outer ring system separates IFG from OFG (Figs. 1, 2; Tichomirowa et al. 2001; Alexowsky et al. 2012; Sebastian 2013), and it experienced emplacement of aphanitic and porphyritic 


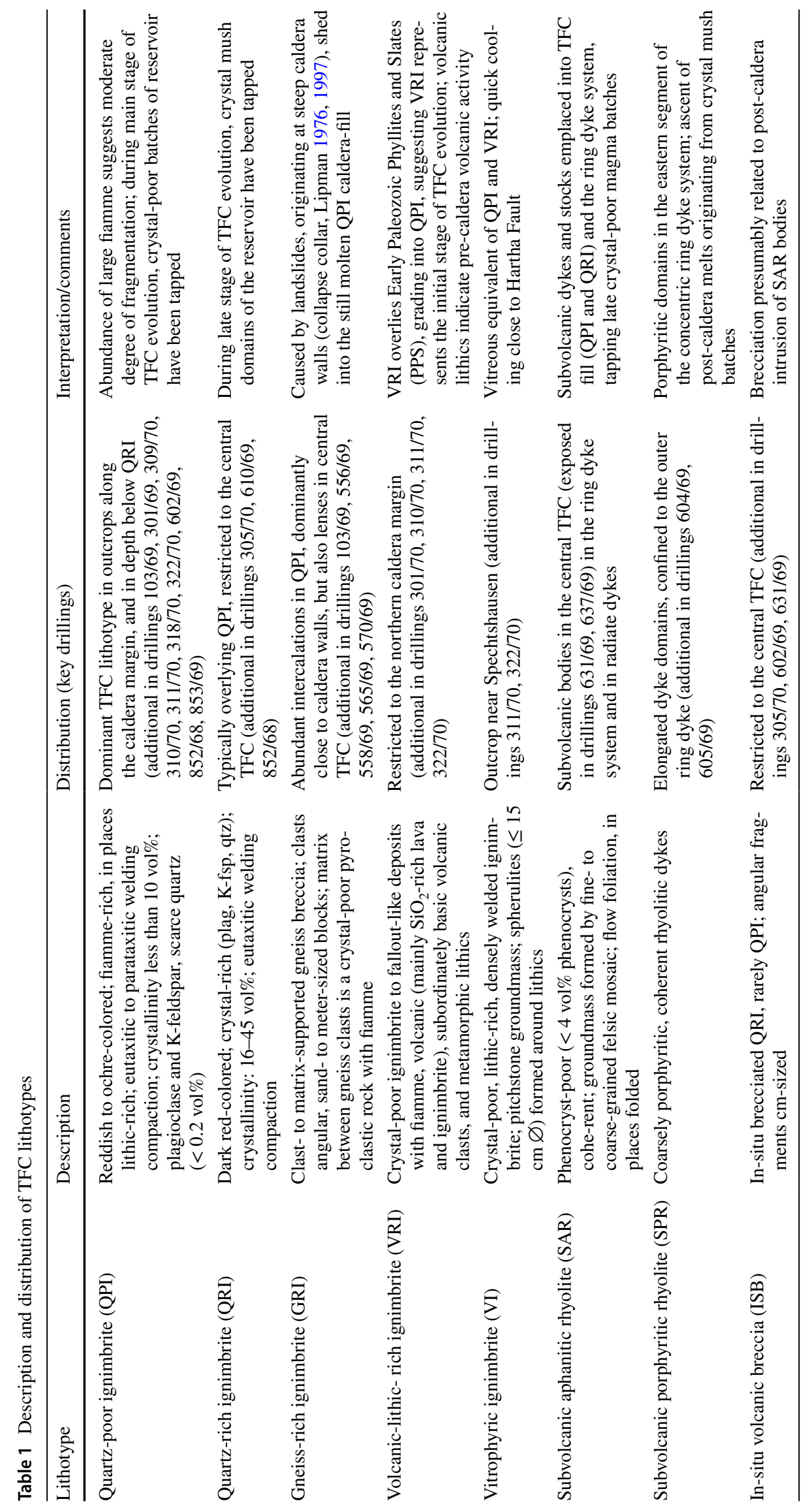


rhyolitic dykes. In the SE-sector, a radial coherent rhyolitic dyke can be followed striking NW-SE (Steinhübel, Fig. 2; Lapp and Breitkreuz 2015). To the west of TFC, rhyolitic dykes trending NNE to SSW (from Hetzdorf to Naundorf; Fig. 2) have been mapped which presumably are related to the outer ring system.

\section{Lithofacies types and their distribution}

The main TFC lithotypes have been described in Table 1 (see Fig. 7 for macroscopic- and Fig. 8 for microscopic textures). Modal composition and maximum particle size (MPS) on quartz and feldspar from selected samples are displayed in Table 2. Biotite, the only known mafic mineral, occurs rarely and strongly altered in most of the TFC lithotypes (Benek 1980). Alexowsky et al. (2012) described the presence of biotite-rich rhyolite at the base of the quartz-rich ignimbrites in drilling 853/69. Lapp and Breitkreuz (2015) noted biotite-rich domains in the NW-SE-trending coherent dyke at Steinhübel.

In the northeast, on the Herrndorf-Hartha Block (HHB), the PPS basement below the TFC fill has been reached by several drillings (Figs. 2, 6, Appendix-Fig. A); the basal successions of QPI are associated with clast-supported pyroclastics (VRI) and with vitreous ignimbrite domains (VI). Along the southern and southeastern TFC margin and, in places, in the central TFC, gneiss-lithic-breccias (GRI) are intercalated within QPI.

QPI is the dominant lithotype of the TFC fill (Figs. 2, 3, 6 and Appendix-Fig. A). It is characterized by low crystallinity $(<10$ vol\%), and in particular by a small amount or absence of quartz crystals ( $\leq 0.2 \mathrm{vol} \%$, Table 2$)$. Plagioclase and K-feldspar crystal clasts comprise $2.9-5.2 \mathrm{vol} \%$ and $0.7-3.6 \mathrm{vol} \%$, respectively (Table 2). QPI is generally rich in fiamme with parataxitic welding compaction (Figs. 7b, 8d, f, Appendix-Fig. B; Quane and Russell 2005). It contains varying amounts of lithics (gneiss, schist and volcanic clasts, Fig. 4b; Benek 1980).

Outcrops and drillings show domains of gneiss-rich breccia and ignimbrites (GRI) at the caldera margins and also in the central part of TFC (Figs. 2, 3, 4b, 6, 7e; Kalmykow et al. 1971; Benek 1980). Intercalated with QPI and QRI (Figs. 2, 3), GRI varies between clast-supported gneiss breccia, and gneiss-rich, matrix-supported ignimbrites, both having a rhyolitic pyroclastic matrix with fiamme, in places. Volcanic lithic-rich ignimbrite (VRI) and related pyroclastic deposits have been detected on the HHB, at the base of the TFC fill, in drillings 301/70, 310/70 and 322/70 (Figs. 2, 6, 7f, g, 8, Appendix Fig. A). Apart from pumice and ex-glass shards, the dominant volcanic lithic type is $\mathrm{SiO}_{2}$-rich lava (Fig. 7b). Subordinately, fragments of basic volcanic rocks (Fig. 8a) and of the metamorphic host of TFC are present (Benek 1980).
The famous "Kugelpechstein" (pitchstone with spherulites) is a vitric ignimbrite (VI), co-genetic to VRI and QPI (Figs. 7h, 8e). It is known since a long time from an outcrop near Hartha (Fig. 2) but it has also been detected in two drillings (311/70, 322/70, Fig. 6, Appendix-Fig. A). All three occurrences are located close to the Hartha Fault which separates TFC from PPS. VI displays a black, welded, quartz-poor vitroclastic texture containing polymict, mainly volcanic lithics. In many cases, the lithics functioned as nuclei for the growth of microlitic spherulites $(\leq 15 \mathrm{~cm}$ in diameter; spheroids accord. to Bryan 1941; Breitkreuz 2013; Lapp and Breitkreuz 2015).

Overlying QPI with a transitional contact (Benek 1980), quartz-rich ignimbrite (QRI) dominates the central TFC (Figs. 2, 3, 6, 7a). As an exception, the documentation for drilling 852/68 revealed an alternation of QPI and QRI (Appendix-Fig. A), however, no core material is preserved for confirmation (see "Caldera evolution"). QRI shows welding compaction and spherulites. Amount of groundmass varies strongly (54.3-83.9 vol\%), the rest comprising varying proportions of quartz, plagioclase and K-feldspar crystal clasts (Table 2).

Much of the concentric and radial ring dykes and the subvolcanic bodies in the TFC centre comprise crystal-poor ( $\leq 4$ vol\% phenocrysts, Table 2 ), in parts flow-foliated, rhyolite rocks (subvolcanic aphanitic rhyolite, SAR, Figs. 2, 3, $7 \mathrm{c}$; Table 1). In addition to SAR, the eastern segment of the ring dyke system and a N-S-trending dyke near Grund expose strongly porphyritic rhyolite domains (subvolcanic porphyritic rhyolite, SPR, Fig. 7i). There, the proportion of felsic groundmass is as low as $57 \mathrm{vol} \%$ (Table 2) and feldspar phenocrysts reach almost one $\mathrm{cm}$ in diameter. Finally, in the central TFC, drillings exposed in-situ brecciated QRI-, rarely QPI rocks (in-situ breccia, ISB, Figs. 2, 3, $7 \mathrm{~d})$. The ISB domains are spatially closely related to SAR dykes, thus, we assume that the brecciation was related to the emplacement of the SAR dykes.

\section{The caldera margin}

\section{The northeastern sector}

On the HHB, drillings 310/70, 311/70, 320/70, 321/70 and $322 / 70$ reached the basement of Early Paleozoic phyllites and slates (PPS) at depth of $218 \mathrm{~m}, 199 \mathrm{~m}, 120 \mathrm{~m}, \mathrm{c} .140 \mathrm{~m}$ and $122.5 \mathrm{~m}$, respectively (Figs. 2, 6 and Appendix-Fig. A). In these drillings, as in 303/70, the overlying volcanoclastic succession is rich in volcanic lithics (VRI) such as rhyolitic lava and welded ignimbrite. For instance, in 311/70 it comprises a $100 \mathrm{~m}$ succession of poorly sorted, matrix- to clastsupported volcanic breccia. At 179-190 m depth, a wellsorted, clast-supported lapillistone (fallout deposit?) has 


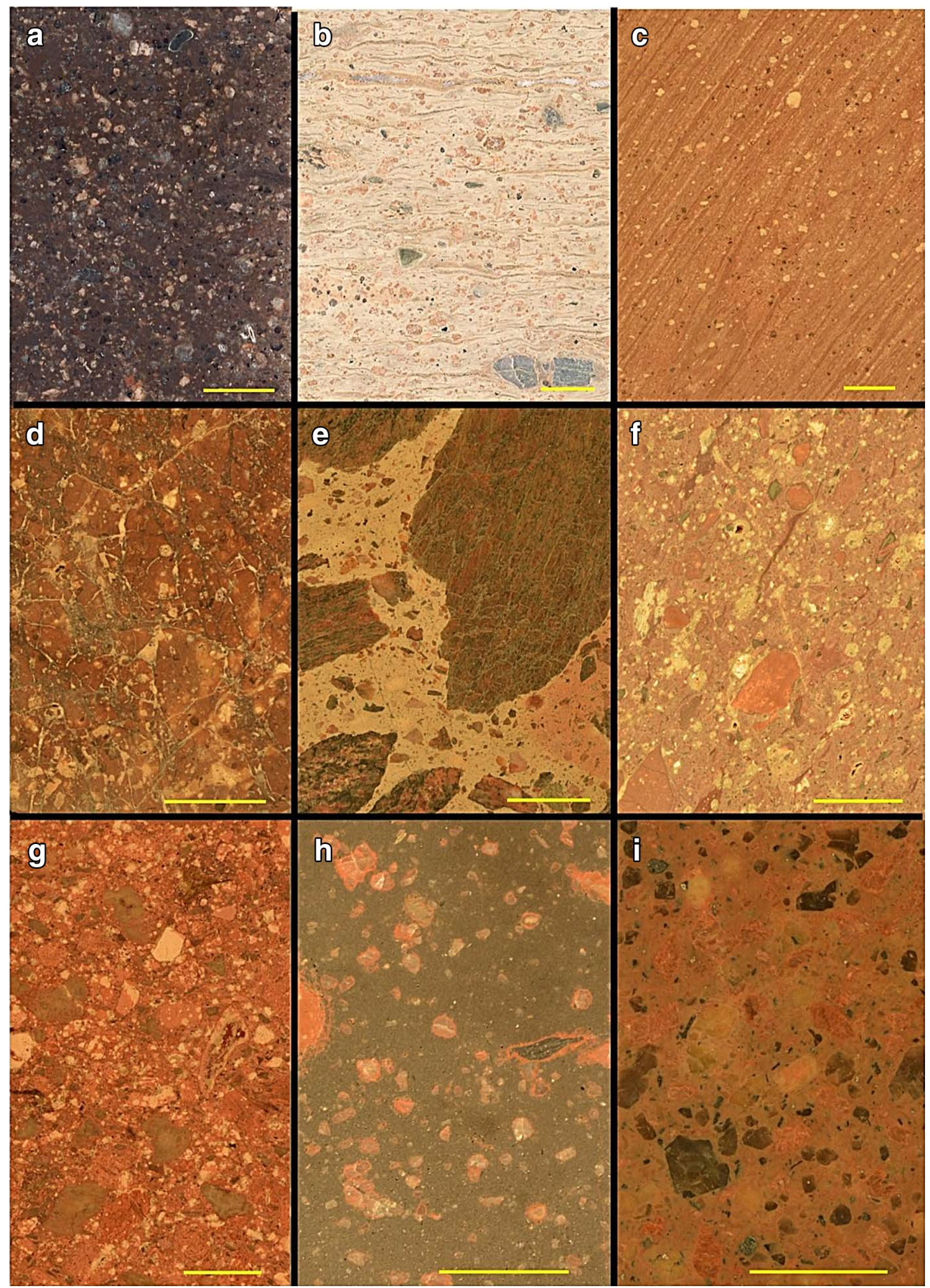


4Fig.7 Photos of polished rock slabs and core halves representing the major TFC lithotypes: a QRI, outcrop sample $\left(50^{\circ} 57^{\prime} 07^{\prime \prime} \mathrm{N}\right.$, $\left.13^{\circ} 28^{\prime} 06^{\prime \prime} \mathrm{E}\right)$; b parataxitic QPI, outcrop sample $\left(50^{\circ} 59^{\prime} 56^{\prime \prime} \mathrm{N}\right.$, $13^{\circ} 28^{\prime} 56^{\prime \prime}$ E); c flow-foliated SAR dyke (drilling 637/69-9.7); d insitu breccia, ISB (drilling 305/70-80.4); e gneiss-rich ignimbrite, GRI (drilling 103/69-38.2); f volcanic-lithic-rich ignimbrite, VRI (drilling 301/70-133.6); g lapillistone, rich in $\mathrm{SiO}_{2}$-rich lava fragments (VRI, drilling 311/70-184.6); h crystal-poor and lithic-rich vitreous ignimbrite, VI (pitchstone; drilling 322/70-111.0); i subvolcanic porphyritic rhyolite (SPR), outer ring dyke (drilling 604/69137.0); for lithofacies acronyms see Table 1 ; scale bar $1 \mathrm{~cm}$

been drilled that is rich in $\mathrm{SiO}_{2}$-rich lava fragments (Fig. $7 \mathrm{~g}$ ). At $98 \mathrm{~m}$ depth, $30 \mathrm{~cm}$ of spherulitic, lithic-rich pitchstone (VI) is overlain by quartz-poor ignimbrite (QPI). Notably, at $133.6 \mathrm{~m}$ depth, drilling $301 / 70$ exposes volcanic lithics of basic composition, indicating a pre-TFC basic volcanic activity in the area (Fig. 8a). In summary, the northeastern sector of the TFC is structured by a southwest-wards downstepping of PPS and overlying TFC fill. Apparently, the HHB documents the initial stage of TFC evolution. Benek (1980) reported dominance of schist lithics in the ignimbrites of this area (Fig. 4b).

Near Tharandt, a N-S-oriented elongated domain of QPI projects into the hosting gneiss and schists (Fig. 2) which could be part of the inner TFC ring system. 3d-measurements on fiamme revealed a sub vertical orientation (Benek 1980, Fig. 4a) suggesting that the promontory served as a major vent zone active during the early TFC evolution.

\section{The southeastern sector}

Drilling 318/70 is located close to the TFC-gneiss contact, with a final depth of $194.3 \mathrm{~m}$ in QPI. This well contains a GRI lens (78.4-133.0 m; Fig. 2, Appendix-Fig. A). Nearby, drillings 556/69 and 565/69 expose c. $95 \mathrm{~m}$ and $45 \mathrm{~m}$ thick domains of GRI, respectively. These field relations illustrate (1) the presence of a steep caldera wall along the inner ring system, and (2) it suggests landslide activity during QPI deposition, caused by instability of the southeastern caldera wall (Lipman 1976, 1997). The juxtaposition of host gneiss, QPI and GRI along the inner ring system is characterized by strong margin-parallel magnetic anomalies (Fig. 5). The outer ring fault system separates a biotite gneiss block (OFG), positioned inside the ring fault, from orthogneiss (IFG) outside the ring fault (Fig. 2; Tichomirowa et al. 2001; Sebastian 2013). The ring also hosts a prominent ring dyke comprising SAR and SPR domains. Near Klingenberg, a ca. 1-km-long NW-SE-trending QPI domain intruded OFG (Fig. 2).

\section{The southwestern sector}

This sector displays a prominent TFC margin-parallel, magnetic anomaly pair (Fig. 5), possibly caused by steep and sharp contact between caldera fill and surrounding paragneiss. East of Naundorf at an artificial scarp (former train track), welded pyroclastic dykes ( $\leq 1.5 \mathrm{~m}$ thick) are exposed cross-cutting gneiss, documenting that magma ascent and fragmentation took place also along the ring dyke system. Furthermore, Kalmykow et al. (1971) and Benek (1980) described a GRI domain, extending for $2.5 \mathrm{~km}$ along the caldera margin (Fig. 2), suggesting that landslides were active also at the caldera wall in the southwestern TFC.

\section{The northwestern sector}

Near Grund, a NE-SW-oriented promontory of QPI and QRI extends from the main TFC fill body into the PPS host (Fig. 2). There, outcrops and drilling 301/70 show steeply oriented fiamme (Fig. 4a, see also Fig. 7f). Benek (1980) stated that the Grund promontory also hosts a "post-ignimbritic" rhyolitic dyke ("Granitporphyr", SPR). Presence of QPI, QRI and the dyke in this promontory suggests that this domain functioned as a magmatic feeder throughout the TFC evolution. In an abandoned quarry near Grund, the "Porphyrfächer", a well-known natural monument (Schwab 1962; Eberlein 2004), shows a fan-like array of curved cooling columns in QPI (Benek 1980; see Fig. 4 in Lapp and Breitkreuz 2015). We assume that the curvature of the columns is related to irregular or faulted contact of QPI with the PPS substrate.

Outside the TFC fill domain (Fig. 2), isolated outcrops of fiamme-rich QPI have been mapped in orthogneiss near Mohorn (and drilling 646/69 not depicted here). In his profile 1, Benek (1980) displayed this ignimbrite occurrence as an erosional remnant. However, Benek showed 3d-orientation of fiamme yielding steep inclinations of $\geq 60^{\circ}$ in this outcrop (Fig. 4a). In this area, the magnetic map shows a NW-SE-oriented negative anomaly (Fig. 5). All these characteristics suggest that the isolated outcrops near Mohorn resemble another TFC vent complex rather than erosional remnants of caldera outflow facies. Furthermore, NNE-SSW-trending rhyolitic dykes have been mapped near Hetzdorf and Naundorf, suggesting a possible continuation of the outer ring fault system in the west (Fig. 2).

\section{The central part of the caldera}

As displayed in Figs. 2 and 3, the central part of the TFC is dominated by quartz-rich ignimbrites (QRI), with sub 

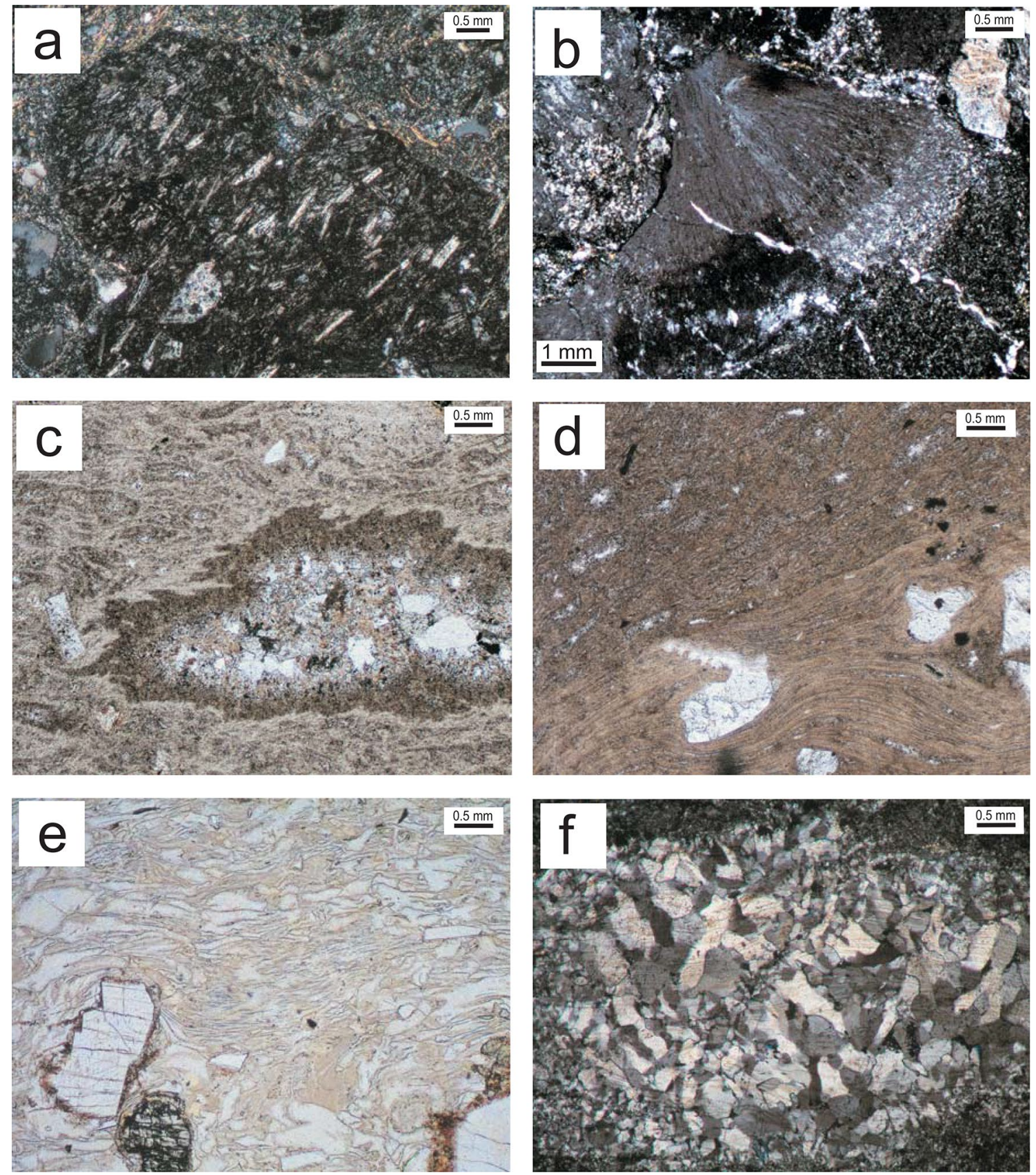

Fig. 8 Microphotographs from TFC thin sections: a basic volcanic lithic with plagioclase prisms in VRI (partial view; drilling 301/70133.6; crossed nicols); $\mathbf{b}$ fragment of a radiate fibrous spherulite in a fallout deposit (VRI; drilling 311/70-184.6; crossed nicols); c eutaxitic fiamme with recrystallized core in a vitroclastic matrix

horizontally oriented fiamme (Fig. 4a; Benek 1980). Drilling 103/69 (Fig. 6) documents c. $80 \mathrm{~m}$ of GRI indicating that some caldera wall landslides reached the central TFC area. Kalmykow et al. (1971) were the first to display subvolcanic aphanitic rhyolite (SAR) in the central TFC (Figs. 2, 3). The complex is spatially closely associated with domains of brittle fragmented QRI (ISB), implying that the emplacement of
(QPI, drilling 318/70-69.7); d parataxitic fiamme (partial view) in vitroclastic matrix (QPI, drilling 322/70-90.0); e vitroclastic welded matrix preserved as pitchstone (VI, drilling 322/70-111.0); f coarsely recrystallized fiamme with preserved texture of elongated vesicles (QPI, drilling 565/69-75.4; crossed nicols)

the rhyolitic SAR melts took place when the QRI has already cooled down. A dense array of $\mathrm{N}-\mathrm{S}$ trending magnetic anomalies is located in the southern central TFC (Fig. 5). Its origin is unclear, we may speculate about the presence of a magmatic feeding complex (see Sect. 5.3). 
Table 2 Modal and MPS analysis on selected TFC lithotypes (Table 1)

\begin{tabular}{|c|c|c|c|c|c|c|c|}
\hline Lithotype; sample & Areal \% quartz & $\begin{array}{l}\text { Areal \% pla- } \\
\text { gioclase }\end{array}$ & $\begin{array}{l}\text { Areal \% } \\
\text { K-feldspar }\end{array}$ & Areal \% lithics & $\begin{array}{l}\text { Areal \% } \\
\text { groundmass }\end{array}$ & $\begin{array}{l}\text { MPS (mm) } \\
\text { quartz }\end{array}$ & $\begin{array}{l}\text { MPS } \\
(\mathrm{mm}) \\
\text { feldspar }\end{array}$ \\
\hline QPI; 103/69-141.0 & & 4.2 & 2.4 & 1.9 & 91.4 & & 3.7 \\
\hline QPI; 103/69-143.9 & 0.2 & 3.4 & 3.6 & 1.9 & 90.9 & 0.6 & 2.8 \\
\hline QPI; 318/70-44.3 & & 5.2 & 3.4 & 0.6 & 90.8 & & 3.1 \\
\hline QPI; 318/70-194.2 & 0.2 & 3.8 & 0.7 & 1.1 & 94.2 & & 2.3 \\
\hline QPI; 507/69-52.9 & 0.1 & 2.9 & 2.5 & 1.1 & 93.4 & 0.4 & 2.4 \\
\hline QRI; 131/69-33.9 & 7.2 & 3.4 & 6.0 & 0.3 & 83.2 & 1.9 & 2.5 \\
\hline QRI; 305/70-42.0 & 8.9 & 2.1 & 4.9 & 0.2 & 83.9 & 2.1 & 1.8 \\
\hline QRI; 610/69-28.0 & 13.7 & 7.7 & 20.9 & 3.4 & 54.3 & 2.1 & 1.8 \\
\hline QRI; 610/69-172.8 & 6.4 & 7.5 & 10.6 & 2.7 & 72.9 & 2.3 & 1.8 \\
\hline SAR; 631/69-40.4 & 0.5 & 1.5 & 0.1 & 2.0 & 96.0 & 1.0 & 1.4 \\
\hline SAR; 637/69-50.8 & 2.8 & 0.0 & 0.0 & 0.0 & 97.2 & 1.3 & \\
\hline SPR; 604/69-137.0 & 14.8 & 11.7 & 15.4 & 0.5 & 57.5 & 3.6 & 4.6 \\
\hline SPR; 605/69-15.9 & 9.4 & 6.4 & 23.7 & 0.3 & 60.1 & 3.3 & 7.8 \\
\hline
\end{tabular}
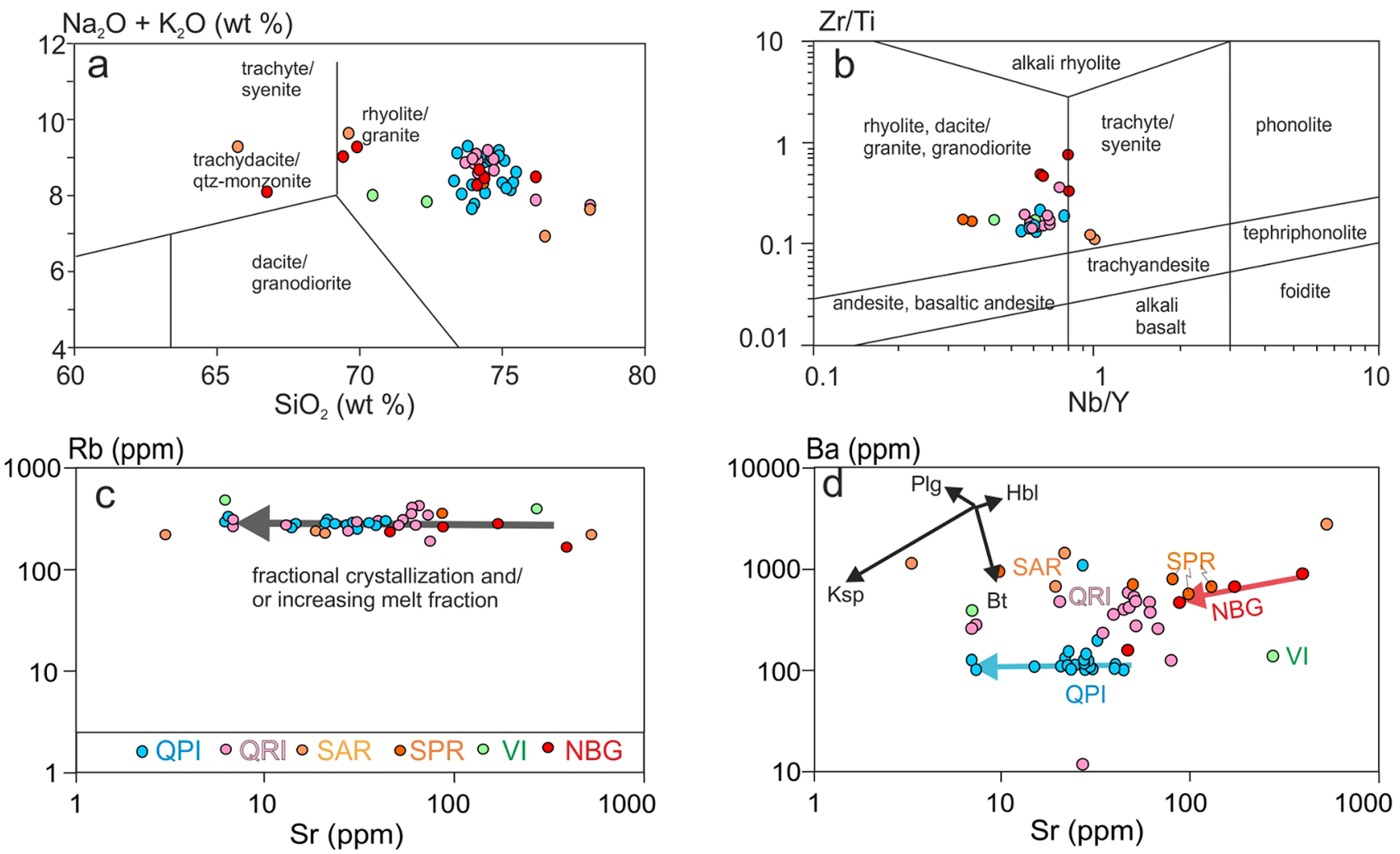

Fig. 9 Whole rock geochemistry of TFC-NBG samples I: a total alkali vs. silica (TAS) plot according to Le Maitre et al. (2002); b Zr/ $\mathrm{TiO}_{2}$ vs. Nb/Y plot according to Pearce (1996); c Rb vs. Sr plot; d

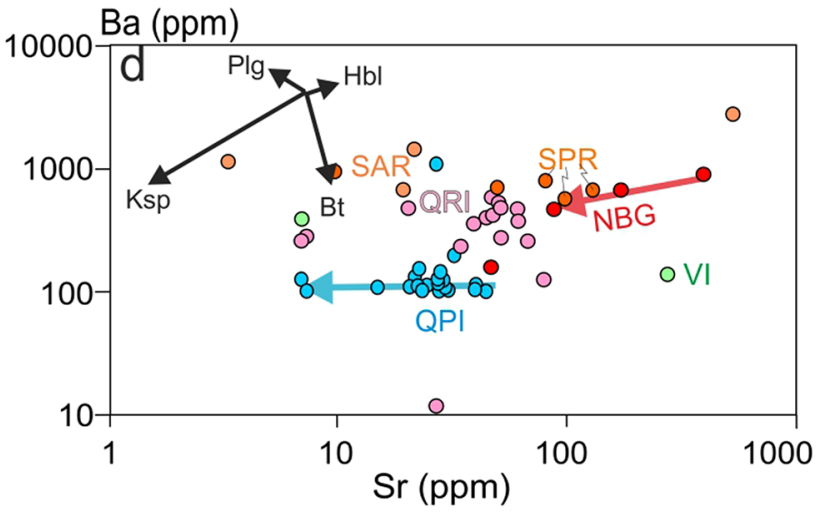

Ba vs. Sr plot; TFC data: Appendix-Tables A and B; NBG data from Förster et al. (1999)

\section{Whole rock geochemistry}

Whole rock geochemistry of TFC (sub-) volcanic rocks (data in Appendix-Tables A and B) and of the adjoined

NBG (Förster et al. 1999) has been plotted in Figs. 9 and 10. The TAS diagram (Fig. 9a; according to Le Maitre et al. 2002) reveals a common rhyolitic composition for the TFC lithologies (see also Alexowsky et al. 2012). NBG ranges 
Fig. 10 Whole rock geochemistry of TFC-NBG samples II: Spider diagrams (a-d) normalized to UCC (Rudnick and Gao 2014), REE plots (e-h) normalized to chondrite according to McDonough and Sun (1995); a and $\mathbf{e} \mathrm{QPI} ; \mathbf{b}$ and $\mathbf{f} \mathrm{QRI} ; \mathbf{c}$ and g SAR, SPR, VI; $\mathbf{d}$ and $\mathbf{h}$ NBG; TFC data: Appendix-Tables A and B; NBG data from Förster et al. (1999)
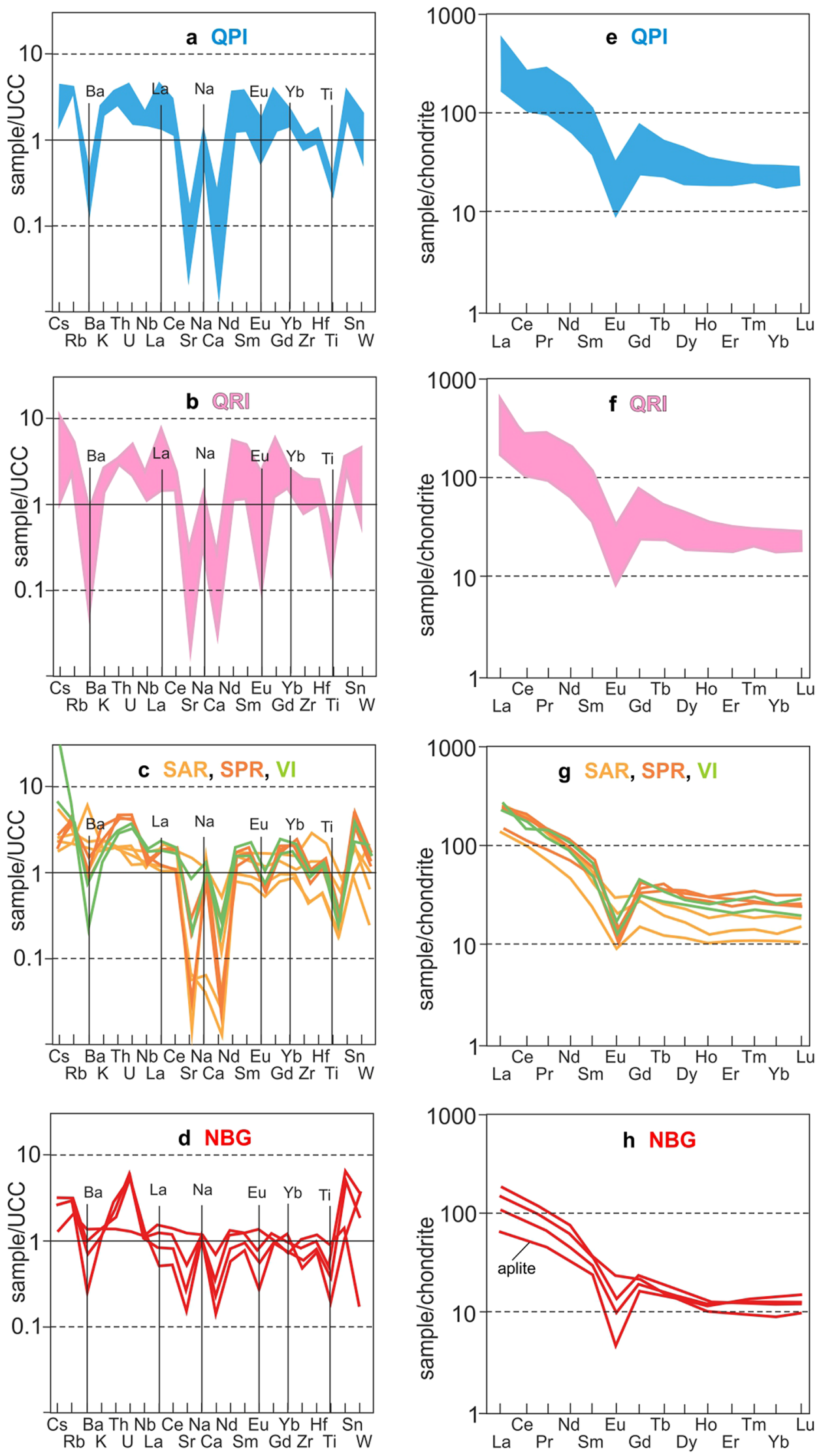
mainly from monzonitic to granitic composition (Fig. 9a). The immobile element plot (Zr/Ti vs. Nb/Y; Fig. 9b; according to Pearce 1996) principally confirms the rhyolitic/dacitic composition while two SAR samples plot into the trachytic field due to their lower Y concentrations. The NBG data display for two samples, a tendency towards trachytic-syenitic composition mainly due to their lower $\mathrm{Y}$ concentrations (Fig. 9b). One of these two samples (with the highest $\mathrm{Zr}$ / Ti ratio-caused mainly by its very low Ti concentration) represents an aplite that has distinct concentrations in many elements (lower Ba, Sr, LREE, Zr, Hf, Ti, but higher Th concentrations), and should be discussed separately. QPI and SAR have the lowest Sr concentrations that might be interpreted as most fractionated melts compared to the less fractionated NBG melts (Fig. 9c). However, for the pyroclastics rocks QRI, QPI and VI, compositional changes due to loss of fine melt clasts during ash cloud formation should be considered. While feldspar fractionation seems to have been dominant for NBG and QPI melts (Fig. 9d), the other TFC rocks display no clear fractionation trend.

Multi-element plots show very similar pattern for QPI and QRI with large negative $\mathrm{Ba}, \mathrm{Sr}, \mathrm{Ca}$ and $\mathrm{Ti}$ anomalies that are less pronounced in some of the SPR and VI samples (Fig. 10). There is no difference between QPI and QRI neither in their REE pattern (Fig. 10e, f) nor in their multielement plots (e.g., Fig. 10a, b) but a slight tendency towards higher $\mathrm{Ba}, \mathrm{Sr}$ (Fig. 9c, d), and slightly higher U concentrations for QRI compared to QPI. The SAR samples show wide variations. All four analyzed samples have high Ba concentrations (Figs. 9d, 10c). The two SAR samples that plot in the trachyte-syenite field (Fig. 9b) are from a drilling, have high $\mathrm{SiO}_{2}-(76.5-78.1 \mathrm{wt} \%)$, high $\mathrm{K}_{2} \mathrm{O}-(6.8-7.4 \mathrm{wt} \%)$, and slightly higher $\mathrm{MgO}$ concentrations. In addition, these two samples have extremely low $\mathrm{Na}, \mathrm{Sr}$, and $\mathrm{Ca}-$, low $\mathrm{Zr}$, $\mathrm{Hf}$ and Ti-, and the lowest HREE contents (Fig. 10g). The two other SAR samples that were collected from surface outcrops contain biotite, and have even higher $\mathrm{MgO}$ contents $(0.5-0.8 \mathrm{wt} \%$, that is higher than all QPI and QRI samples), and high $\mathrm{TiO}_{2}$ contents (0.38-0.47 wt \%; again higher than all QPI and QRI samples). Distinctly to the two SAR samples from drilling, one of the outcrop samples has very high $\mathrm{Sr}, \mathrm{Na}, \mathrm{Ca}, \mathrm{Zr}$, and $\mathrm{Hf}$ concentrations. This sample has the lowest $\mathrm{SiO}_{2}\left(65.7 \mathrm{wt} \%\right.$ ), and the highest $\mathrm{Al}_{2} \mathrm{O}_{3}, \mathrm{FeO}_{\text {total }}$, $\mathrm{MgO}$, and $\mathrm{TiO}_{2}$ concentrations and probably represents the least fractionated sample. Therefore, the SAR samples show very distinct concentrations of both, compatible and incompatible trace elements. Similarly, SPR samples display wide variations in their geochemistry with few samples again being extremely depleted in $\mathrm{Sr}$ and $\mathrm{Ca}$ while others show much less depletion in these elements (Fig. 10c). However, all SPR samples have lower $\mathrm{Ba}$ and higher $\mathrm{Sr}$ concentrations compared to SAR (Fig. 9d). The two analyzed VI samples (one from a drilling, the other from a surface outcrop) again are quite different in their geochemical pattern (Fig. 10c). The four samples from NBG (Förster et al. 1999) have only slightly lower $\mathrm{SiO}_{2}$ contents, and higher $\mathrm{MgO}, \mathrm{TiO}_{2}, \mathrm{CaO}$, $\mathrm{Al}_{2} \mathrm{O}_{3}$, and $\mathrm{FeO}_{\text {total }}$ concentrations. Except for the highly fractionated aplite, they have distinctly less pronounced $\mathrm{Eu}$ anomalies, and the lowest REE concentrations (both LREE and HREE, Fig. 10h). Compared to all (sub)volcanic samples, they have the lowest degree of fractional crystallization resulting in various but less evolved negative anomalies for $\mathrm{Ti}, \mathrm{Eu}, \mathrm{Ca}$, and $\mathrm{Sr}$ in multi-element plots (Fig. 10d). In summary, NBG and SPR samples correspond to the least evolved melts while most QRI melts show an intermediate degree. The highest degree of fractional crystallization can be assigned to the majority of QPI and SAR samples (Fig. 9c, d).

\section{Radiometric ages}

The $\mathrm{U}-\mathrm{Pb}$ isotopic results of five samples are given in Table 3 and presented in Fig. 11 as ${ }^{206} \mathrm{~Pb} /{ }^{238} \mathrm{U}$ age ranked plots for each individual sample (sample location in Fig. 2). Nine to 24 grains were analyzed for each sample. Mean sample ages were calculated from age clusters that are interpreted as crystallization ages. The error of weighted mean ages is given as $\pm x / y / z$ where $x$ is the internal $2 \sigma$ measurement error, $y$ is the internal $2 \sigma$ error plus tracer calibration uncertainty, and $z$ additionally includes the uncertainty of the decay constant (Schoene et al. 2006).

24 zircons were dated from sample NBG 1 of the Niederbobritzsch granite. The first five zircons leached for $12 \mathrm{~h}$ (standard leaching; see Methods; fraction "a" in Table 3) yielded ages from 236.1 to $314.1 \mathrm{Ma}$. The large age scatter was interpreted due to severe $\mathrm{Pb}$ loss so that an additional step of leaching (another $12 \mathrm{~h}$; fraction "b" in Table 3, " $24 \mathrm{~h}$ CA" in Fig. 11) was applied to 18 further zircon grains. Except one very young age (233.3 Ma) and one xenocrystic age (407.6 Ma), the remaining 16 analyses resulted in a much smaller age spread (from 311.0 to $322.4 \mathrm{Ma}$ ). The age of $322.4 \mathrm{Ma}$ is at least $4 \mathrm{Ma}$ higher than all remaining dates and is therefore interpreted as a zircon antecryst (Miller et al. 2007). All other zircons form a continuous range from 311 to $318 \mathrm{Ma}$ where the younger ages may be explained by slight $\mathrm{Pb}$ loss. To test this hypothesis, a third leaching step (additional $12 \mathrm{~h}$ resulting in $36 \mathrm{~h}$ total leaching; fraction "c" in Table 3, "36 h CA" in Fig. 11) was applied. After such severe leaching, only one measurement was possible yielding 318.2 Ma. This age is identical with two other dates (the oldest) resulting in a weighted mean age of 318.2 $\pm 0.3 / 0.3 / 0.5 \mathrm{Ma}$ for this sample (Fig. 11).

17 zircons were dated from sample NBG 2 mainly yielding ages from 315 to $322 \mathrm{Ma}$ with three considerably younger ages $(208,275,304 \mathrm{Ma})$. One grain yielded a distinctly older age (322 Ma) and is interpreted as an antecryst. 


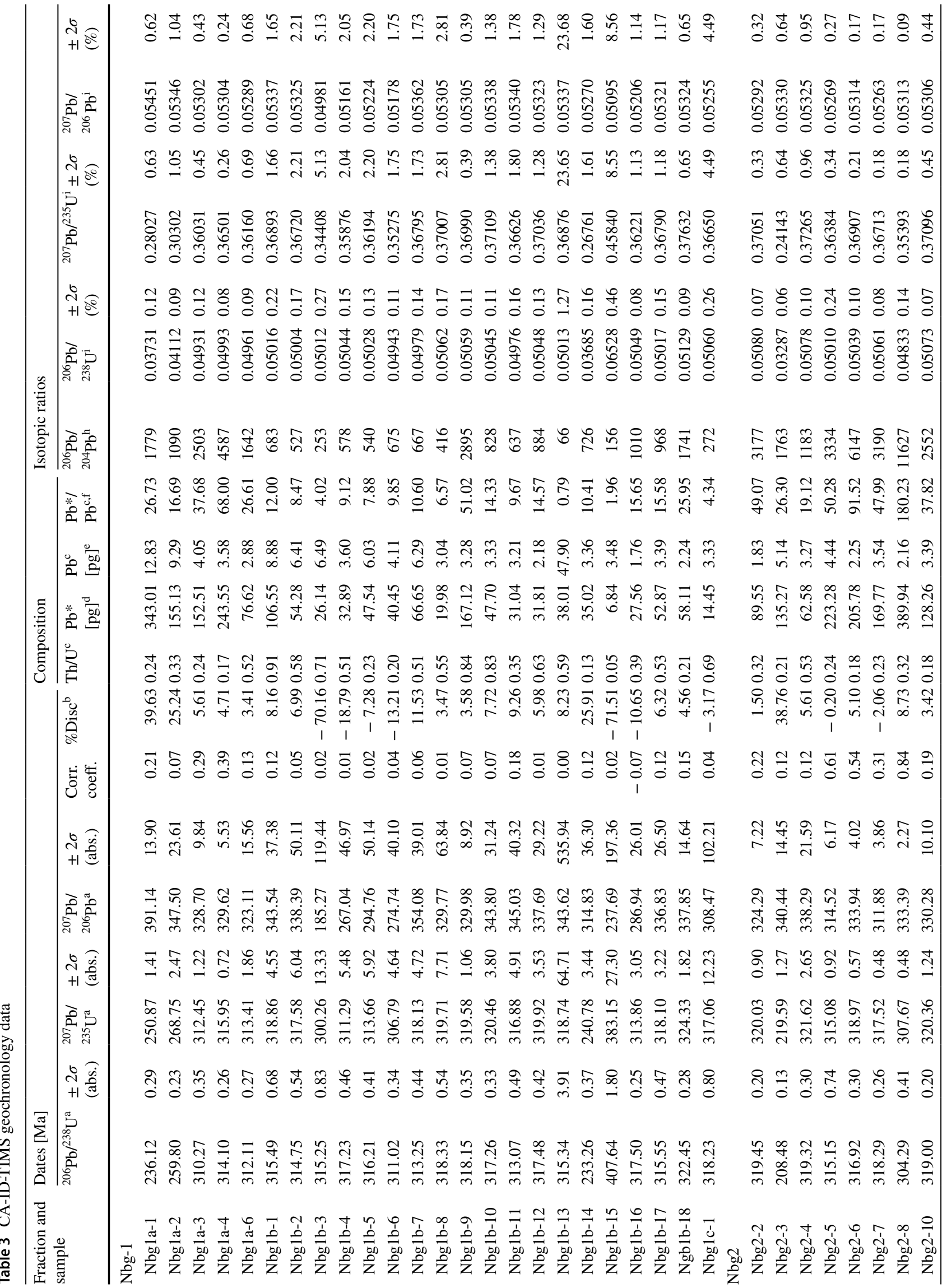




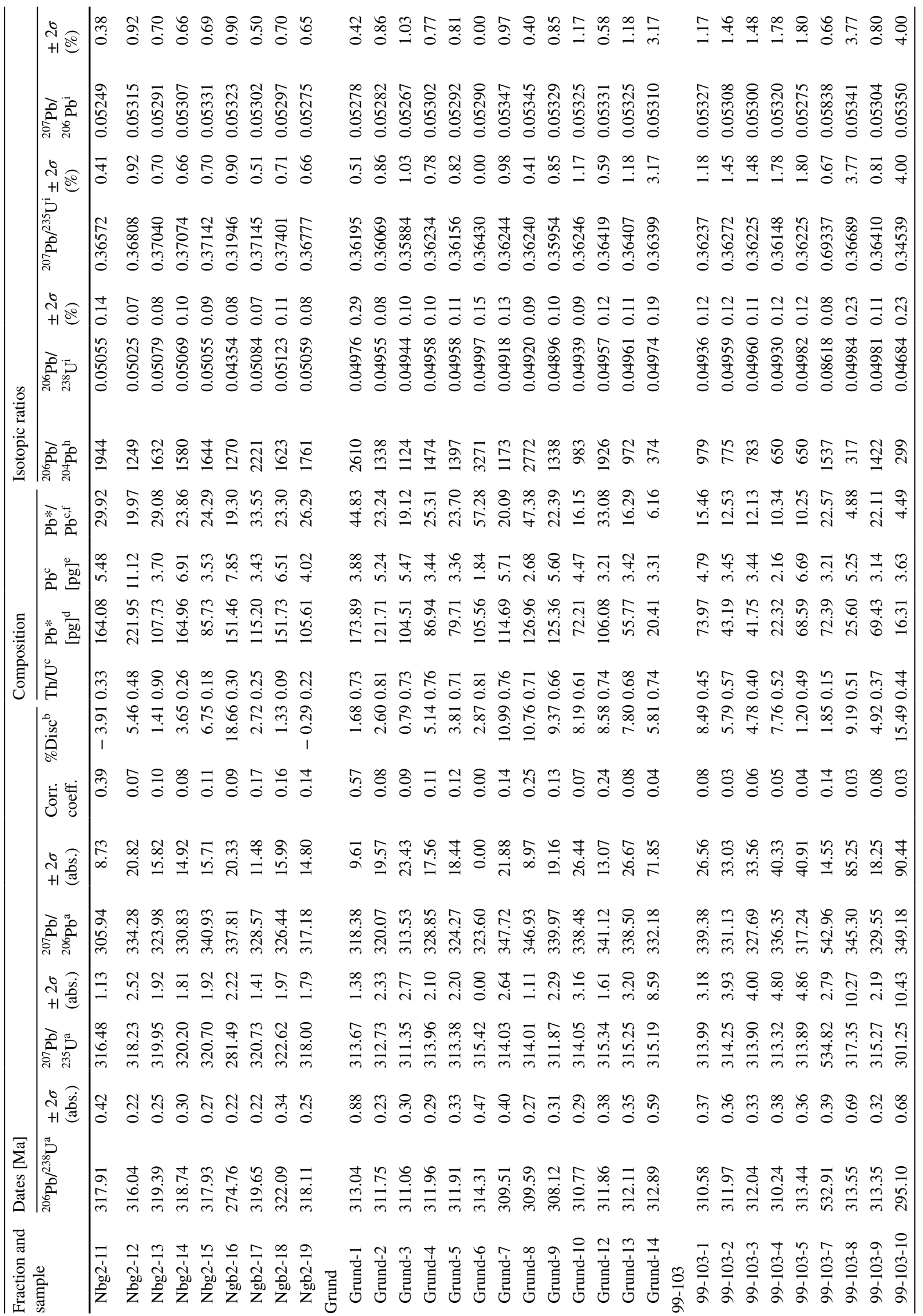




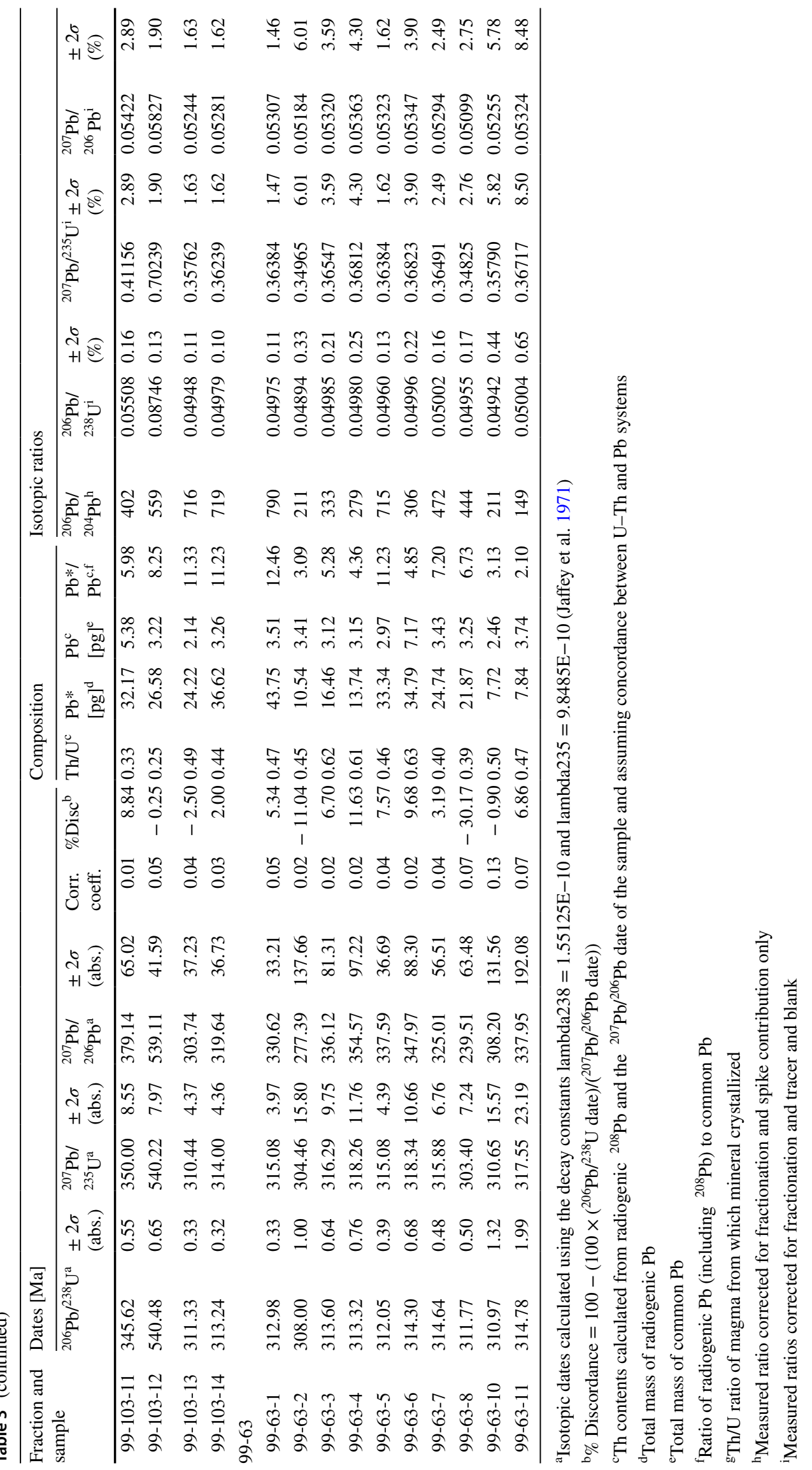


We calculated a weighted mean age from the four oldest dates resulting in $319.5 \pm 0.1 / 0.2 / 0.4 \mathrm{Ma}$ (Fig. 11) and explain the tail towards younger ages for the remaining zircons as slight $\mathrm{Pb}$ loss.

For TFC, two samples were dated ("Grund", 99-103). 13 zircons from sample Grund (QPI) yielded ages between 308 and $314 \mathrm{Ma}$. Five grains define an age cluster with $311.9 \pm 0.1 / 0.2 / 0.4 \mathrm{Ma}$ interpreted as the crystallization age. We suggest that the five younger zircons suffered from slight $\mathrm{Pb}$ loss while the three older zircons represent antecrysts.

13 zircons were dated from sample 99-103 (small N-Soriented SAR dyke in QRI east of Hetzdorf). Three measurements can be assigned to xenocrysts (540, 533, $346 \mathrm{Ma}$ ). One analysis is distinctly younger ( $295 \mathrm{Ma}$ ). The remaining nine zircons scatter between 310.2 and 313.6 Ma with four measurements forming an age cluster with identical ages resulting in 313.4 $\pm 0.2 / 0.2 / 0.4 \mathrm{Ma}$ interpreted as the crystallization age of this sample.

For the outer ring dyke, sample 99-63 was analyzed. Ten zircons were dated where the three oldest zircons form an age cluster resulting in a calculated mean age of $314.5 \pm 0.4 / 0.4 / 0.5 \mathrm{Ma}$. The remaining seven younger zircons from sample 99-63 suffered from slight $\mathrm{Pb}$ loss.

In summary, we obtained an intrusion age for the NBG between $318.2 \pm 0.5$ and $319.5 \pm 0.4 \mathrm{Ma}$. The two samples from TFC are $\geq 5$ Ma younger $(311.9 \pm 0.4$; $313.4 \pm 0.4 \mathrm{Ma})$ while the sample from the outer ring dyke is slightly $(\leq 1 \mathrm{Ma})$ older than the other two TFC samples $(314.5 \pm 0.5 \mathrm{Ma})$.

\section{Discussion}

Based on previous studies, including geophysical data, and the new textural, geochemical, geochronological information presented here, a number of issues on the evolution of the TFC-NBG complex will be discussed. These include the relation between the quartz-poor and -rich ignimbrites, the caldera geometry, -evolution and -timing, magnetic data, and estimates on volume and erosion.

\section{Caldera type and anatomy}

The TFC is a typical plate (piston) -type caldera with steeply dipping caldera ring faults (Cole et al. 2005; Lipman 2007). Walker (1984) distinguished between calderas which experienced incremental growth and those which formed during a single catastrophic eruption. During the climactic phase of TFC, eruption of quartz-poor to quartz-rich magma took place apparently with no eruptive breaks (as would be indicated by sedimentary intercalations or paleosoils). Apparently TFC comprises a single pulse caldera system.
Gneiss-lithic-rich breccias (GRI) are a prominent feature of TFC associated with the formation of QPI and QRI (Figs. 2, 3, 12). Lithic-rich domains in caldera systems can be deposited by pyroclastic flows (co-ignimbritic lag breccias, Walker 1985) or they resemble rock avalanche deposits related to caldera wall instability and landslides (Lipman 1976). Polymict composition of initial TFC pyroclastics (VRI) preserved on the HHB suggests that lag breccias should also be polymict containing different types of lithics. Instead, the GRI is monomict exclusively comprising angular gneiss fragments up to $1 \mathrm{~m}$ in size (monolithic mesobreccia, Lipman 1976). The pyroclastic matrix of GRI suggests that the debris avalanches originated from steep caldera walls (collapse collar, Lipman 1997) and plunged into and mingled with the still plastic pyroclastic material.

During the post-caldera phase of the TFC, SAR formed as central intrusions, and as ring and radial dykes. SPR domains formed in the outer ring dyke system and in the N-S-oriented dyke near Grund. Sample 99-63 from the ring dyke yielded an age of $314.5 \pm 0.4 \mathrm{Ma}$. Thus, parts of the ring dyke system formed early during TFC evolution. However, modal composition of most of the ring dyke rhyolites renders unlikely a role as a major feeding system for the climactic TFC eruption.

Possibly, the inner and the outer ring faults were positioned inside TFC close to its margin. Later erosion removed caldera fill and possible post-caldera lava domes. Postcaldera vent rings, situated on cone sheet-type fractures, are related to updoming rather than to caldera subsidence (Walker 1984). Steeply inward-dipping fiamme orientation observed at the margins of TFC (Fig. 4a) favors presence of inward dipping ring fractures (Walker 1984). A literature survey on some 160 calderas led Walker (1984) to conclude that post-caldera vents often occupy a central position, as with the SAR bodies in central TFC. Apparently no resurgence of the caldera floor occurred. This assumption is supported by the sub horizontal $3 \mathrm{~d}$ orientation of fiamme in central TFC (Fig. 4a).

\section{Estimates on volume and erosion}

On the map presented here (Fig. 2), the TFC fill covers about $52 \mathrm{~km}^{2}$ (50 km² accord. to Benek 1980; Förster et al. 2008). Based on outcrop features and geometric considerations, Benek assumed a thickness of $600 \mathrm{~m}$ for QPI, and $\leq 300 \mathrm{~m}$ for QRI in the central TFC. Drilling 853H/69 revealed a minimum thickness of $371.4 \mathrm{~m}$ for QPI in the central part of TFC (Fig. 6). Drilling 610/69 exposes $176 \mathrm{~m}$ of QRI. Assuming a cumulative minimum thickness of $550 \mathrm{~m}$ for the central and southern TFC and a mean depth of $180 \mathrm{~m}$ for the PPS basement on the HHB in the northeast, we calculated a minimum volume of $22 \mathrm{~km}^{3}$ of preserved caldera fill (Förster et al. 2008: $25-30 \mathrm{~km}^{3}$ ). Sub recent calderas with a structural 
diameter of $10 \mathrm{~km}$, like TFC, produced a total volume of erupted magma in the order of $100 \mathrm{~km}^{3}$ (Geshi et al. 2014). Mason et al. (2004) stated that many sub recent calderas produced roughly equal volumes of caldera fill, caldera outflow and co-ignimbritic ash deposits. However, these relations have to be applied with caution (Cook et al. 2016). Assuming some $33 \mathrm{~km}^{3}$ of original TCF fill indicates that erosion removed c. $11 \mathrm{~km}^{3}$, translating into a minimum erosion of c. $210 \mathrm{~m}$ of caldera fill. Thus, about an upper third of the TFC fill has been removed by Late Paleozoic to pre-Cenomanian erosion (Fig. 12). These estimations position TFC into the lower size class of Permian-Carboniferous volcanic centres in central Europe (Table 4).

\section{Relation between geology and magnetic anomalies}

The Cenozoic basaltic domains west and northwest of Hartha are marked by pronounced anomaly pairs (Figs. 1, 5). Strong magnetic anomaly pairs also follow the inner TFC ring fault (Figs. 2, 5) presumably reflecting the lithological contrast between caldera fill and hosting gneiss and/or dykes. This is in contrast to the outer fault/dyke system: (1) The NE-SW-trending rhyolitic dykes mapped between Hetzdorf and Naundorf, and the group of pyroclastic domains north of Hetzdorf (Fig. 2) are not displayed by magnetic anomalies (Fig. 5). (2) Similarly, the outer ring dyke/fault in the east and south of TFC (near Colmnitz and Klingenberg), prominent in the geological map (Fig. 2), is not reflected in magnetic anomalies. The small negative anomaly west of Grillenburg may be related to the central subvolcanic complex (SAR, ISB; Figs. 2, 3, 5). Only the radiate dyke east of Klingenberg, including the Steinhübel, is marked by a moderate positive magnetic anomaly (Figs. 2, 5).

The NE-SW- to N-S-oriented array of strong magnetic anomalies south of Grillenburg has no clear equivalence in the available geological data, except its vicinity to the inner ring fault system. As we discuss below, it might resemble part of a late stage magmatism and caldera subsidence (Figs. 12, 13). NW-SE- and NE-SW-trending faults in the HHB interpreted from the magnetic data by Kalmykow et al. (1971; Fig. 5), suggest that this block is structurally complex, in contrast to the simplified display in Figs. 2 and 12.

\section{Caldera evolution}

\section{Pre-caldera phase}

On the HHB, several drillings exposed initial clast- to matrix-supported pyroclastics (VRI) that contain fragments of $\mathrm{SiO}_{2}$-rich lava (dome) and, subordinately, ignimbrite- and basic volcanics. The VRI deposits resemble fallout lapilli beds formed during an initial (?sub-) Plinian eruption phase. The population of lithics indicates small-scale $\mathrm{SiO}_{2}$-poor to -rich volcanic activity in the area prior to TFC eruption (Fig. 12). The wide variation of the geochemical composition of VRI samples most probably relates to mixing of such diverse (basic to acid) volcanic fragments.

\section{Early climactic phase}

The early climactic phase comprises the formation of voluminous QPI caldera fill associated with pronounced subsidence of the caldera floor. Subsidence concerned the central TFC part and the HHB (Fig. 12). The latter is inferred from VI domains, located close to the Hartha Fault, its formation caused by swift cooling. Abundance and size of large fiamme suggests poor fragmentation and resulting pyroclastic fountaining along NW-, N-S-, and NE-SW-oriented fissures (Tharandt, Mohorn, Grund), and along ring faults, tapping a crystal-poor, geochemically highly differentiated part of the TFC magma reservoir (e.g., high $\mathrm{SiO}_{2}$ 73.5-75.1 wt\%; low $\mathrm{MgO} 0.05-0.28 \mathrm{wt} \%)$. Eruption from multiple vents is also supported by the distribution of lithics in the caldera fill with a dominance of gneiss lithics in the south and of schists in the north (Fig. 4b).

During this phase, steep caldera walls formed, where instability led to landslides at the eastern and southern segments of the caldera wall. The gneiss debris plunged into the still hot caldera fill. Most of the landslide material has been detected at the caldera margin along the inner ring fault, however some landslides reached the southern part of the central TFC. It remains unclear whether the landslides originated from the walls of the inner and/or of the outer ring fault system. As mentioned before, a formation of ring dykes in this early phase is indicated by the CA-ID-TIMS age of sample 99-63. The chemical composition of this sample is similar to those from the highly evolved QPI melts (high $\mathrm{SiO}_{2} 74.2 \mathrm{wt} \%$, low $\mathrm{MgO} 0.16 \mathrm{wt} \%$, Appendix-Table B).

\section{Late climactic phase}

Caldera fill transits from quartz-poor (QPI) to -rich composition (QRI), suggesting tapping of another, more crystallized, and geochemically less differentiated magma batch (Fig. 9). Actually, the mode of sample 610/69-28.0 with c. 42 vol\% crystals qualifies as crystal mush (Table 2; Huber et al. 2012). In the course of the early to late climactic phase, welding compaction affected the accumulating caldera fill leading to a bowl-shaped geometry of the $3 \mathrm{~d}$ fiamme orientation (Fig. 4a, Benek 1980).

Many large caldera-forming systems build up mid- to upper crustal magma reservoirs over long time periods (Folkes et al. 2011; Myers et al. 2019) where crystallization upon cooling alternated with reheating by underplating or injection. In places, e.g., in the Late Paleozoic Wurzen volcanic system in northern Saxony, magma mingling occurred, 


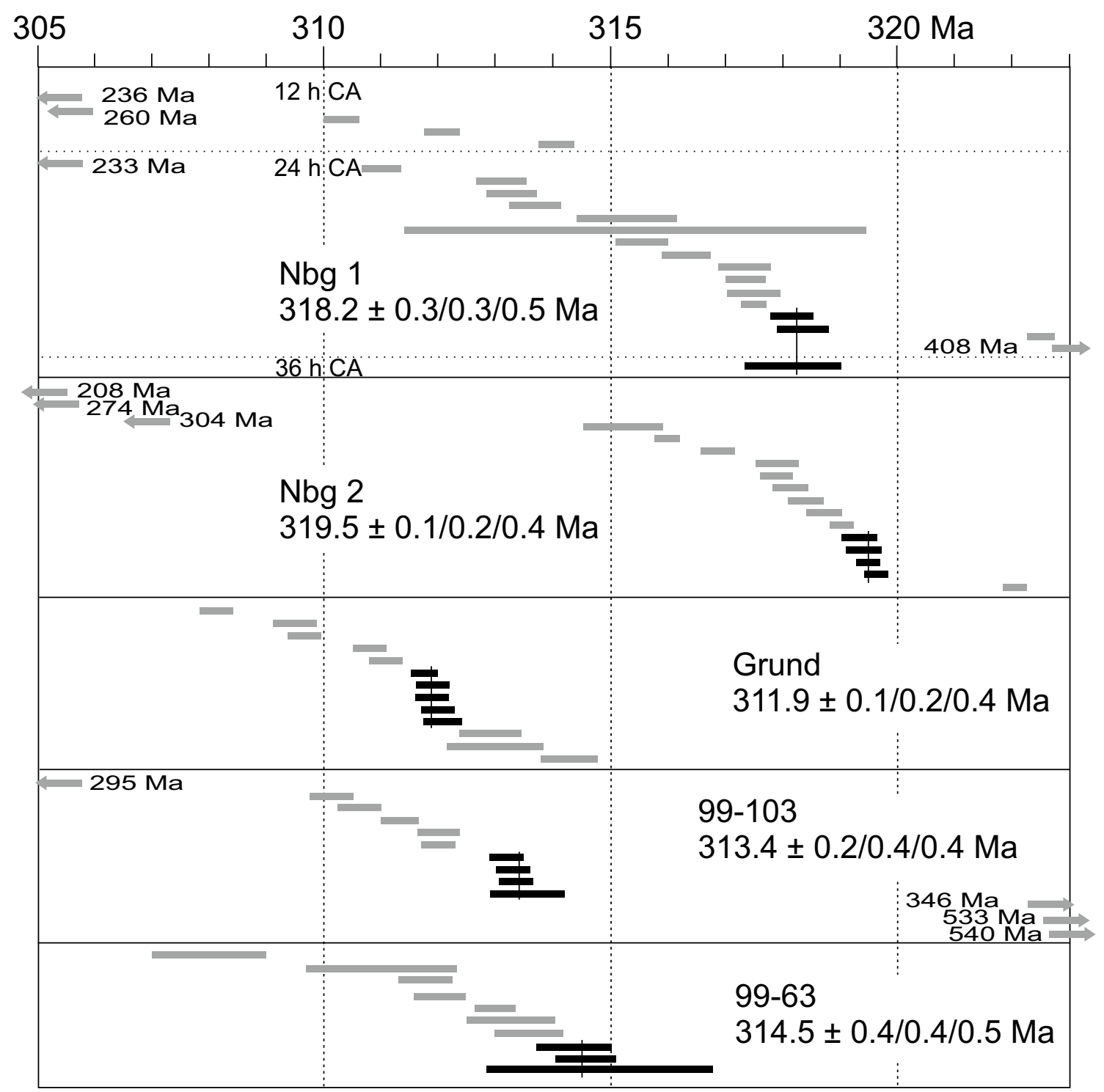

Fig. 11 Single grain zircon analyzes and ${ }^{206} \mathrm{~Pb} /{ }^{238} \mathrm{U}$ weighted mean ages for the dated samples (see Fig. 2 and Table 3). Each single zircon grain/fragment analysis including its $2 \sigma$ uncertainty is represented by a horizontal bar. Grey bars are not included in the calculation of weighted mean ages. The weighted mean ages are shown by

documented by fiamme and minerals of different geochemical composition (Repstock et al. 2018). In the TFC fill ignimbrites, no such variations have been recorded.

Benek (1980) presented a lithostratigraphic column of the TFC fill with QPI forming the lower part, overlain by QRI. This succession is generally confirmed by the geological map (Fig. 2) with QRI occupying the central part of the TFC, and by a number of drillings (Figs. 2, 6). However, drillings 852/68 and 131/69 (Fig. 6 and Appendix Fig. B) reveal TFC domains where QPI overlies QRI or where these lithologies alternate. The designation to one of the two lithologies in Figs. 3, 6 and Appendix Fig. A mainly relies on the original vertical lines. Uncertainty in the weighted mean ages are reported as $x / y / z$ where $x$ is the internal $2 \sigma$ measurement error, $y$ is the internal $2 \sigma$ error plus tracer calibration uncertainty, and $z$ additionally includes the uncertainty of the decay constant (Schoene et al. 2006)

drilling documentations which were based on macroscopic or hand lens examination. We were able to verify the quartz phenocryst content only for some drilling sections (blue signature in Fig. 6 and Appendix Fig. A). Our modal analysis of nine samples show quartz content between 0.0 and $0.2 \mathrm{vol} \%$ for QPI and 6.4-13.7 vol\% for QRI (Table 2). Theoretically, the observed distribution of QPI and QRI domains may have been caused by temporally synchronous tapping of quartzrich and -poor magma batches during the climactic phase of TFC. Also, post-depositional, density-controlled vertical movement of the still hot TFC fill may have played a role to explain the observed distribution. 


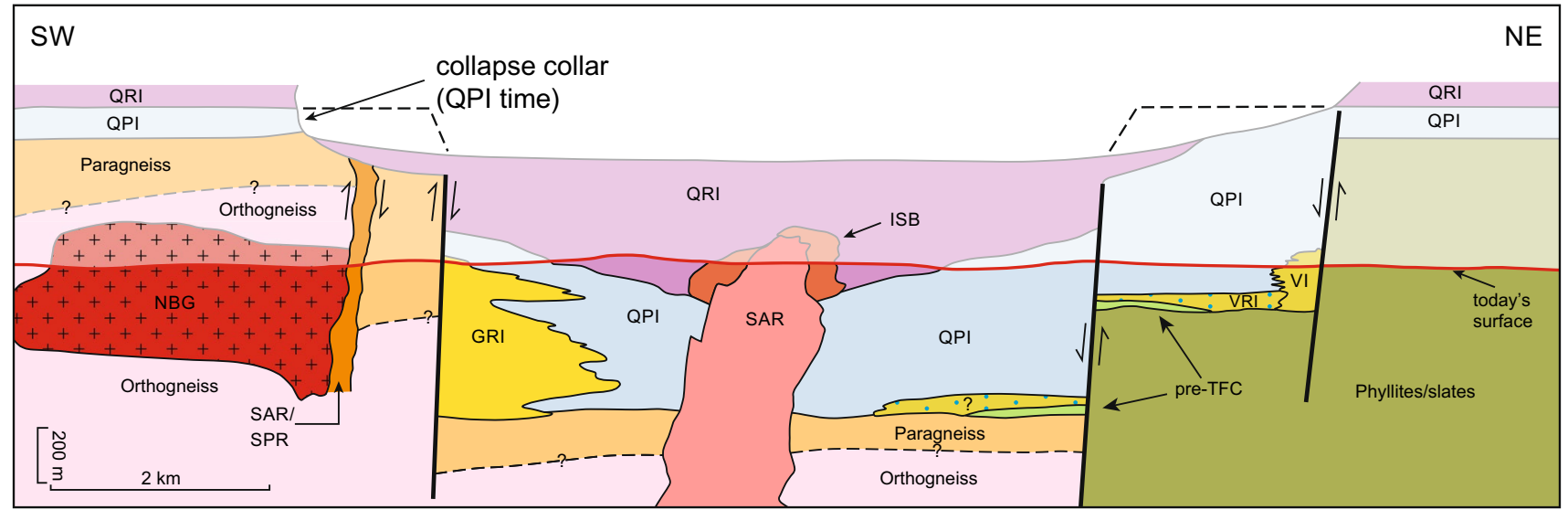

Fig. 12 Schematic NE-SW profile through the TFC-NBG complex, depicting the assumed pre-erosion scenario; GRI gneiss-rich ignimbrite, $I S B$ in-situ breccia, $N B G$ Niederbobritzsch granite, $Q P I$ : quartzpoor ignimbrite, $Q R I$ quartz-rich ignimbrite, $S A R$ sub volcanic apha-

Figure 13 shows the Bouguer gravity map of the TFC-NBG area, and the main ring- and radiate dyke/ fault systems of TFC, copied from Figs. 2 and 5. During Stage 1, related to the eruption of quartz-poor magma, subsidence took place along the outer ring dyke/fault and the Hartha fault. During this early phase, the pyroclastic apophyses east of Mohorn and near Tharandt formed. Stage 1 does not stand out in the gravimetric image due to a missing density contrast within the gneiss domains. The preserved caldera fill circumscribed by the Stage 2 ring dykes/faults caused a pronounced negative gravity anomaly (Fig. 13). Stage 2 faults and dykes are also clearly marked by magnetic anomalies (Fig. 5). Benek (1980) noted that the pyroclastic/coherent apophysis near Grund also contain QRI material, implying that it served as an active feeder throughout the climactic phase. A somewhat speculative Stage 3 dyke/fault near Grillenburg is inferred from the curved magnetic anomalies (Fig. 5). In summary, TFC resembles a telescoped caldera system, its subsidence proceeded in two, perhaps three stages.

\section{Post-caldera phase}

Sub horizontal 3d-orientation of fiamme in the central TFC (Fig. 4a) renders caldera resurgence unlikely. Instead, the central part of the TFC fill experienced intrusion of SAR provoking brittle deformation of apparently cool QRI (ISB; Kennedy et al. 2012). Post-caldera updoming (Walker 1984) of the Freiberg gneiss dome resulted in the formation of ring and radiate dyke systems harboring SAR and SPR. nitic rhyolite, SPR sub volcanic porphyritic rhyoulite, TFC Tarandt Forest caldera, VI vitrophyric ignimbrite, VRI volcanic lithic-rich ignimbrite

\section{Relation of TFC with NBG and the evolution of the Freiberg gneiss dome}

The NBG is cropping out southwestwardly adjacent to the TFC ring fault system (Figs. 1, 2, 12, 13). Above we estimated the possible minimum amount of post-caldera erosion in the order of $210 \mathrm{~m}$. Thomas (1994), and Thomas and Klemm (1997) estimated emplacement levels of 6.5-3 km for Variscan granites from the Erzgebirge (including NBG) based on melt inclusion studies. This implies that there was a phase of considerable denudation of the Freiberg gneiss dome prior to caldera eruption. The NBG represents an earlier period of upper crustal magma accumulation in the central area of the Freiberg gneiss dome as supported by the new CA-ID-TIMS ages showing that NBG is about $5 \mathrm{Ma}$ older than TFC. The geochemical composition of this biotite bearing granite corresponds to lowest degree of melt differentiation (e.g., lowest $\mathrm{SiO}_{2} 66.8-74.2 \mathrm{wt} \%$, higher $\mathrm{MgO}$ 0.46-1.4 wt\%; higher $\mathrm{TiO}_{2} 0.25-0.59 \mathrm{wt} \%$; less evolved Eu-anomaly; Figs. 9a and 10d, h). Eruption of TFC marks the final phase in the evolution of the NBG-TFC magma complex. In the TFC, virtually no granite clasts have been observed (Benek 1980) implying that the NBG was not exposed at the southern caldera wall when the monomict GRI-forming landslides occurred.

The longstanding magmatic activity of the TFC-NBG complex was accompanied by upper crustal doming. After NBG incremental emplacement, doming, presumably by emplacement of hypothetical (not discovered yet) magmatic bodies below NBG, and erosion took place bringing the NBG closer to the Late Carboniferous paleosurface ( $2 \mathrm{~km}$ uplift within $5 \mathrm{Ma}$ would result in $0.4 \mathrm{~mm} /$ year). The 
Table 4 Areal extent and volume estimates of major Permian-Carboniferous caldera and subvolcanic complexes in central Europe

\begin{tabular}{lccc}
\hline Name (locality) & Diameter/area & $\begin{array}{l}\text { Estimated magma } \\
\text { volume }\left(\mathrm{km}^{3}\right)\end{array}$ & References \\
\hline Ora caldera (northern Italy) & $1680 \mathrm{~km}^{2}$ & $>1290^{\mathrm{a}}$ & Willcock et al. (2013) \\
Wurzen caldera (northern Saxony, eastern Germany) & $1500 \mathrm{~km}^{2}$ & $>200^{\mathrm{a}}$ & Repstock et al. (2018) \\
Rochlitz caldera (northern Saxony, eastern Germany) & $54 \mathrm{~km}$ & 1060 & Hübner et al. in revision \\
Altenberg-Teplice volcanic complex (southern Saxony/northern Czechia) & $630 \mathrm{~km}^{2}$ & $\geq 320^{\mathrm{a}}$ & Casas García et al. (2019) \\
Tarandt Forest caldera (central Saxony, eastern Germany) & $10 \mathrm{~km}$ & $22^{\mathrm{a}}$ & This presentation \\
Halle Volcanic Complex (eastern Germany), mainly subvolcanic & $25 \mathrm{~km}$ & 300 & Breitkreuz et al. (2018) \\
Flechtingen subvolcanic andesite (near Magdeburg, Germany) & $20 \mathrm{~km}$ & 10 & Luthardt et al. (2020) \\
\hline
\end{tabular}

${ }^{\text {a} P r e s e r v e d ~ c a l d e r a ~ f i l l ; ~ o n l y ~ O r a ~ c a l d e r a ~ i n c l u d e s ~ m i n o r ~ c a l d e r a ~ o u t f l o w ~ d e p o s i t s ~}$

pronounced caldera subsidence during the climactic TFC phase juxtaposed the NBG and the caldera fill in the southwestern sector of TFC. Of the longstanding (? $5 \mathrm{Ma}$ ) magmatic activity of TFC-NBG complex at least four phases are documented by outcrops and drillings: (1) the incrementally grown NBG, (2) small-scale pre-TFC volcanic activity, clasts of which have been drilled on HHB, (3) the climactic TFC eruption fed from a number of fissures, and (4) the post-caldera intrusion of rhyolitic subvolcanic bodies.

\section{Magmatic activity and inter-basin correlation}

The NBG intruded slightly later compared to the oldest granitic plutons in the Western Erzgebirge (Aue-Schwarzenberg at 323-322 Ma) but coeval with further Variscan granites that belong to the "Older igneous complex" (see Sect. 2). The formation of TFC took place slightly later than the formation of the evolved tin granite pluton in the Western Erzgebirge (Eibenstock: 315-314 Ma; Tichomirowa et al. 2019). TFC-NBG has partially overlapping radiometric ages with ATVC (325-317 Ma, Casas García et al. 2019; Tomek et al. 2021), suggesting a more or less synchronous or overlapping activity of both volcanic complexes. Radiometric ages of volcanic and volcaniclastic rocks in neighboring basins, such as Döhlen-, Brandov-Olbernhau-, Flöha- and Chemnitz basins (Hoffmann et al. 2013, Luthardt et al. 2018, Löcse et al. 2019; Zieger et al. 2019) are $\geq 10$ Ma younger than TFC. Volcaniclastic deposits in the Hainichen Early Molasse basin yielded a radiometric age of $330 \pm 4 \mathrm{Ma}$ (Gehmlich et al. 2001), and thus is older than TFC. In conclusion, distal tuffs or caldera outflow facies of TFC are not known so far.

\section{Conclusion}

The ca. 40-km-wide Freiberg gneiss dome presumably formed due to episodic ascent of silicic magma in the Bashkirian-Moscovian (Pennsylvanian) building up a

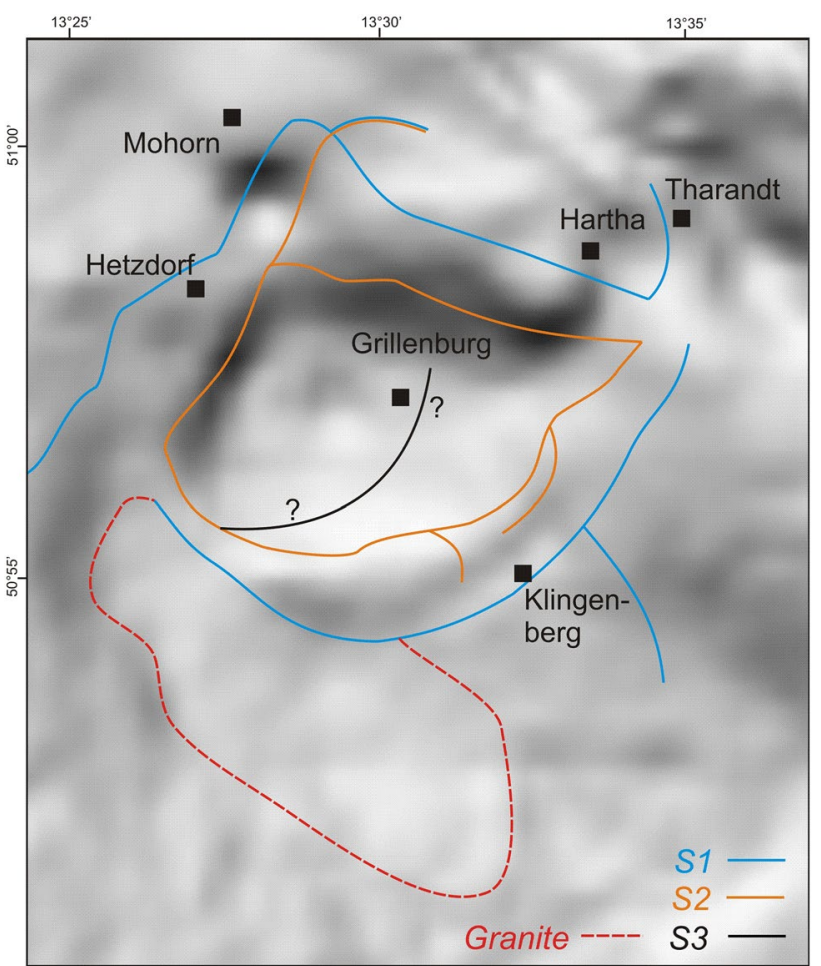

Fig. 13 Bouguer map of the TFC-NBG area (Saxony State Survey for Agriculture, Environment and Geology, Freiberg, Germany, unpubl. file) displaying a sub circular negative anomaly (light grey) caused by the rhyolitic caldera fill; the small pronounced anomaly in the northwest, south of Mohorn, presumably depicts one of the major TFC vents; Stages S1-3: assumed position of ring and radiate dyke/ fault systems; for discussion see text; for location see Figs. 2 and 5

mid- to upper crustal reservoir with a longstanding activity. The Niederbobritzsch Granite (NBG, $319 \mathrm{Ma}$ ) represents an early phase of the magmatic activity while the Tharandt Forest caldera eruption (TFC, 312-314 Ma) and post-caldera dyking mark the final episode. Field relations suggest that, between NBG and TFC formation, substantial updoming and erosion took place. 
TFC displays characteristics of a piston-type caldera presumably performing a single pulse caldera floor subsidence. TFC eruption was initiated by (?sub-) Plinian fallout including volcanic fragments from pre-TFC volcanic activity. In a first phase, during the climactic eruption, fed by a multi-vent system, a phenocryst-poor rhyolitic, highly differentiated magma batch has been tapped, later, more crystal-rich, less evolved melts ascended. Landslides from steep caldera walls (collapse collar) led to the formation of monolithic mesobreccia. During and after the climactic eruption, aphanitic and porphyritic rhyolitic melts emplaced in central TFC, and in ring and radiate dyke systems. Comparing the TFC geometry with data from (sub-) recent calderas world-wide, we assume a minimum volume of $22 \mathrm{~km}^{3}$ of preserved caldera fill. This can be translated into a minimum erosion of $210 \mathrm{~m}$.

Supplementary Information The online version contains supplementary material available at https://doi.org/10.1007/s00531-021-02015-x.

Acknowledgements We are very grateful to Axel Hiller (Wismut $\mathrm{GmbH}$ ) for permitting access to and use of TFC drilling documentation and drill cores! In particular, we thank for allowance to use the maps of Kalmykow et al. (1971). We appreciate discussions with Ottomar Krentz (Freiberg). Dougal Jerram and an anonymous reviewer are much thanked for providing constructive reviews.

Funding Open Access funding enabled and organized by Projekt DEAL.

Open Access This article is licensed under a Creative Commons Attribution 4.0 International License, which permits use, sharing, adaptation, distribution and reproduction in any medium or format, as long as you give appropriate credit to the original author(s) and the source, provide a link to the Creative Commons licence, and indicate if changes were made. The images or other third party material in this article are included in the article's Creative Commons licence, unless indicated otherwise in a credit line to the material. If material is not included in the article's Creative Commons licence and your intended use is not permitted by statutory regulation or exceeds the permitted use, you will need to obtain permission directly from the copyright holder. To view a copy of this licence, visit http://creativecommons.org/licenses/by/4.0/.

\section{References}

Alexowsky W, Berger H-J, Horna F, Jaschke I, Kurze M, Renno A, Stanek K, Schneider JW, Tröger K-A (2012) Erl. Geol. Kt. Sachsen 1:25.000, B1. 5047 Freital (3. Aufl.) Freiberg: p 180 (in German)

Awdankiewicz M, Breitkreuz C, Ehling B-C (2004) Emplacement textures in Late Palaeozoic andesite sills of the Flechtingen-Roßlau Block, north of Magdeburg (Germany). Geol Soc Lond Spec Publ 234:51-66

Benek R (1980) Geologische-strukturelle Untersuchungen im Tharandter Vulkanitkomplex (Südteil DDR). Zeitschrift der Deutschen Geologischen Gesellschaft 8:627-643 (in German)

Benek R, Harff J (1981) Bemerkungen zum Internbau von Vulkanitkomplexen, speziell des Tharandter Komplexes. Zeitschrift der Deutschen Geologischen Gesellschaft 9(11):1253-1257 (in German)
Benek R, Kramer W, McCann T, Scheck M, Negendank J, Korich D, Huebscher H-D, Bayer U (1996) Permo-Carboniferous magmatism of the Northeast German Basin. Tectonophysics 266:379-404

Black LP, Kamo SL, Allen CM, Aleinikoff JN, Davies DW, Korsch RJ, Foudoulis C (2003) TEMORA 1: a new zircon standard for phanerozoic U-Pb geochronology. Chem Geol 200:155-170

Breiter K, Novák JK, Chlupácová M (2001) Chemical evolution of volcanic rocks in the Altenberg-Teplice Caldera (Eastern Krušné hory, Czech Republic, Germany). Geolines 13:17-22

Breitkreuz C (2013) Spherulites and lithophysae-200 years of investigation on high-temperature crystallization domains in silica-rich volcanic rocks. Bull Volcanol 75:1-16

Breitkreuz C, Kennedy A, Geissler M, Ehling B-C, Kopp J, Muszynski A, Protas A, Stouge S (2007) Far Eastern Avalonia: its chronostratigraphic structure revealed by SHRIMP zircon ages from Upper Carboniferous to Lower Permian volcanic rocks (drill cores from Germany, Poland and Denmark). Geol Soc Am Spec Pap 423:173-190

Breitkreuz C, Ehling B-C, Pastrik N (2018) The subvolcanic units of the Late Paleozoic Halle Volcanic Complex, Germany: geometry, internal textures and emplacement mode. In: Breitkreuz C, Rocchi $\mathrm{S}$ (eds) Physical geology of shallow magmatic systems. Springer, Heidelberg, pp 295-307

Bryan WH (1941) Spherulites and allied structures, Part I. Proc R Soc Qld Aust 52:41-53

Casas García R, Rapprich V, Breitkreuz C, Svojtka M, Lapp M, Stanek K, Hofmann M, Linnemann U (2019) Lithofacies architecture, composition, and age of the Carboniferous Teplice Rhyolite (German-Czech border): Insights into the evolution of the AltenbergTeplice Caldera. J Volcanol Geotherm Res 386

Cole JW, Milner DM, Spinks KD (2005) Calderas and caldera structures: a review. Earth Sci Rev 69:1-26

Condon DJ, Schoene B, McLean NM, Bowring SA, Parrish RR (2015) Metrology and traceability of $\mathrm{U}-\mathrm{Pb}$ isotope dilution geochronology (EARTHTIME Tracer Calibration Part I). Geochim Cosmochim Acta 164:464-480

Cook GW, Wolff JA, Self S (2016) Estimating the eruptive volume of a large pyroclastic body: the Otowi Member of the Bandelier Tuff, Valles caldera, New Mexico. Bull Volcanol 78(2):10

Eberlein M (2004) Die Geotope des Tharandter Waldes: Inventarisierung und Bewertung. Unpubl. Diploma thesis, TU Dresden, $p$ 150 (in German)

Folkes CB, de Silva SL, Wright HM, Cas RA (2011) Geochemical homogeneity of a long-lived, large silicic system; evidence from the Cerro Galán caldera, NW Argentina. Bull Volcanol 73(10):1455-1486

Förster H-J (1998) Die variszischen Granite des Erzgebirges und ihre akzessorischen Minerale. Unpubl. Habil. Thesis, Techn. Univ. Bergakademie Freiberg, Germany, p 168 (in German)

Förster H-J (2000) Cerite-(Ce) and Thorian Synchysite-(Ce) from the Niederbobritzsch Granite, Erzgebirge, Germany: implications for the differential mobility of the LREE and Th during alteration. Can Mineral 38:67-79

Förster H-J, Davis JC, Tischendorf G, Seltmann R (1999) Multivariate analyzes of Erzgebirge granite and rhyolite composition: implications for classification of granites and their genetic relations. Comput Geosci 25:533-546

Förster H-J, Tischendorf G, Pälchen W, Benek R, Seltmann R (2008) 3.4 Spätvariszischer Magmatismus. In: Pälchen W, Walter H (eds) Geologie von Sachsen. E. Schweizerbart'sche Verlagsbuchhdlg., Stuttgart: 257-296 (in German)

Galetto F, Acocella V, Caricchi L (2017) Caldera resurgence driven by magma viscosity contrasts. Nat Commun 8:1750

Gehmlich M, Linnemann U, Tichomirowa M, Gaitzsch B, Bombach K (2001) Geochronologie oberdevonischer bis unterkarbonischer Magmatite der Thüringischen und Bayerischen Faziesreihe sowie 
variszischer Deckenkomplexe und der Frühmolasse von BornaHainichen (Saxothuringisches Terrane). Zeitschr Deutsch Geol Gesell 151:337-363 (in German)

Geißler M, Breitkreuz C, Kiersnowski H (2008) Late Paleozoic volcanism in the central part of the Southern Permian Basin (NE Germany, W Poland): facies distribution and volcano-topographic hiati. Int J Earth Sci 97:973-989

Geshi N, Ruch J, Acocella V (2014) Evaluating volumes for magma chambers and magma withdrawn for caldera collapse. Earth Planet Sci Lett 396:107-115

Gregg PM, De Silva SL, Grosfils EB, Parmigiani JP (2012) Catastrophic caldera-forming eruptions: thermomechanics and implications for eruption triggering and maximum caldera dimensions on Earth. J Volcanol Geotherm Res 241:1-12

Henry CD, Kunk MJ, Muehlberger WR, McIntosh WC (1997) Igneous evolution of a complex laccolith-caldera, the Solitario, TransPecos Texas: implications for calderas and subjacent plutons. Geol Soc Am Bull 109(8):1036-1054

Hoffmann U, Breitkreuz C, Breiter K, Sergeev S, Stanek K, Tichomirowa $M$ (2013) Carboniferous-Permian volcanic evolution in Central Europe-U/Pb-ages of volcanic rocks in Saxony (Germany) and northern Bohemia (Czech Republic). Int J Earth Sci 102:73-99

Hoth K, Eilers H, Fritzsche H (1992): Geologische Übersichtskarte des Freistaates Sachsen 1:400.000, 3. Edition (in German)

Huber C, Bachmann O, Dufek J (2012) Crystal-poor versus crystalrich ignimbrites: a competition between stirring and reactivation. Geology 40(2):115-118

Hübner M, Breitkreuz C, Repstock A, Schulz B, Pietranik A, Lapp M, Heuer F Development of the Lower Permian Rochlitz volcanic system, Eastern Germany: textural and geochemical requirements on an intra-continental supereruption. Int J Earth Sci (in revision)

Jaffey AH, Flynn KF, Glendenin LE, Bentley WC, Essling AM (1971) Precision measurement of half-lives and specific activities of ${ }^{235} \mathrm{U}$ and ${ }^{238}$ U. Phys Rev C. https://doi.org/10.1103/PhysRevC.4.1889

Kalmykow VD, Haberland P, Gehrke R, Korotkov SI, Kocetkov VI (1971) Geologischer Bau und Uranhöffigkeit des Tharandter Waldes. Unpubl. Report of SDAG Wismut (in Russian, with two maps in Russian and German)

Kelley SA, McIntosh WC, Goff F, Kempter KA, Wolff JA, Esser R, Braschayko S, Love D, Gardner JN (2013) Spatial and temporal trends in pre-caldera Jemez Mountains volcanic and fault activity. Geosphere 9(3):614-646

Kennedy B, Stix J (2007) Magmatic processes associated with caldera collapse at Ossipee ring dyke, New Hampshire. Geol Soc Am Bull 119:3-17

Kennedy B, Wilcock J, Stix J (2012) Caldera resurgence during magma replenishment and rejuvenation at Valles and Lake City calderas. Bull Volcanol 74:1833-1847

Kováŕíková P, Siebel W, Jelínek E, Štemprok M, Kachlik V, Holub FV, Blecha V (2007) Petrology, geochemistry and zircon age for redwitzite at Abertamy, NW Bohemian Massif (Czech Republic): tracing the mantle component in Late Variscan intrusions. Geochemistry 67(2):151-174

Kröner A, Willner AP, Hegner E, Frischbutter A, Hofmann J, Bergner R (1995) Latest Precambrian (Cadomian) zircon ages, Nd isotopic systematics and $\mathrm{p}-\mathrm{T}$ evolution of granitoid orthogneisses of the Erzgebirge, Saxony and Czech Republic. Geol Rundsch $84: 437-456$

Lange H, Tischendorf G, Pälchen W, Klemm I, Ossenkopf W (1972) Zur Petrographie und Geochemie der Granite des Erzgebirges. Geologie 21:457-493

Lapp M, Breitkreuz C (2015) Die spätpaläozoischen Vulkanzentren im östlichen Erzgebirge. In: Kirnbauer T (ed) Geologische Exkursionen in Sachsen und Brandenburg. Jahresber Mitteil Oberrhein Geol Ver N F 97: 143-168 (in German)
Le Maitre RW, Streckeisen A, Zanettin B, Le Bas MJ, Bonin B, Bateman P, Bellieni G, Dudek A, Efremova S, Keller J, Lamere J, Sabine PA, Schmid R, Sorensen H, Woolley AR (2002) Igneous Rocks: A Classification and Glossary of Terms, Recommendations of the International Union of Geological Sciences, Subcommission of the Systematics of Igneous Rocks. Cambridge University Press

Lipman PW (1976) Caldera-collapse breccias in the western San Juan Mountains, Colorado. Geol Soc Am Bull 87:1397-1410

Lipman PW (1997) Subsidence of ash-flow calderas: relation to caldera size and magma-chamber geometry. Bull Volcanol 59(3):198-218

Lipman PW (2007) Calderas. In: Sigurdsson H (ed) Encyclopedia of volcanoes. Academic Press, San Diego, pp 643-662

Löcse F, Linnemann U, Schneider G, Merbitz M, Rößler R (2019) First U-Pb LA-ICP-MS zircon ages assessed from a volcano-sedimentary complex of the mid-European Variscides (Pennsylvanian, Flöha Basin, SE Germany). Int J Earth Sci 108(2):713-733

Luthardt L, Hofmann M, Linnemann U, Gerdes A, Marko L, Rößler $\mathrm{R}$ (2018) A new U-Pb zircon age and a volcanogenic model for the early Permian Chemnitz Fossil Forest. Int J Earth Sci 107(7):2465-2489

Luthardt L, Breitkreuz C, Schneider J., Gaitzsch B, Brink J, Stanek KP, Linnemann U, Hofmann M, Ehling B-C (2020) An andesitic sill complex in the Southern Permian Basin: volcanogenetic model and stratigraphic implications. Int J Earth Sci 109:2447-2466

Lützner H, Tichomirowa M, Käßner A, Gaupp R (2021) Latest Carboniferous to early Permian volcano-stratigraphic evolution in Central Europe-U/Pb CA-ID-TIMS ages of volcanic rocks in the Thuringian Forest Basin (Germany). Int J Earth Sci 110:377-398

Mason BG, Pyle DM, Oppenheimer C (2004) The size and frequency of the largest explosive eruptions on Earth. Bull Volcanol 66(8):735-748

Mattinson JM (2005) Zircon U-Pb chemical abrasion ("CA-TIMS") method: combined annealing and multi-step partial dissolution analysis for improved precision and accuracy of zircon ages. Chem Geol 220:47-66

McDonough WF, Sun SS (1995) The composition of the Earth. Chem Geol 120:223-253

Miller J, Matzel J, Miller C, Burgess S, Miller R (2007) Zircon growth and recycling during the assembly of large, composite arc plutons. J Volcanol Geotherm Res 167:282-299

Moesta G (1928) Brüche und Porphyreffusionen im östlichen Erzgebirge. Zeitschrift Deutsch Geol Gesell 80 (Abh) Berlin: 343-408 (in German)

Myers ML, Wallace PJ, Wilson CJ (2019) Inferring magma ascent timescales and reconstructing conduit processes in explosive rhyolitic eruptions using diffusive losses of hydrogen from melt inclusions. J Volcanol Geotherm Res 369:95-112

Pearce JA (1996) A user's guide to basalt discrimination diagrams. In: Wyman DA (ed) Trace element geochemistry of volcanic rocks: applications for massive sulphide exploration. Geol Assoc Canad, Short Course Notes, 12:79-113

Pietzsch K (1914) Erläuterungen zur geologischen Spezialkarte des Königreichs Sachsen, Sektion Tharandt, Blatt 81.-2. Aufl. Leipzig: p 125 (in German)

Quane SL, Russell JK (2005) Ranking welding intensity in pyroclastic deposits. Bull Volcanol 67(2):129-143

Repstock A, Breitkreuz C, Lapp M, Schulz B (2018) Voluminous and crystal-rich igneous rocks of the Permian Wurzen Volcanic System, northern Saxony, Germany: physical volcanology and geochemical characterization. Int J Earth Sci 107:1485-1513

Röllig G (1976) Zur Petrogenese und Vulkanotektonik der Pyroxenquarzporphyre (Ignimbrite) des Nordwestsächsischen Vulkanitkomplexes. Jahrb Geol 5/6, Berlin: 175-268 (in German) 
Romer RL, Meixner A, Förster H-J (2014) Lithium and boron in lateorogenic granites-isotopic fingerprints for the source of crustal melts? Geochim Cosmochim Acta 131:98-114

Rösler HJ, Budzinski H (1994) Das Bauprinzip des Granits von Niederbobritzsch bei Freiberg (Sa.) auf Grund seiner geochemischen Analyze. Z Geol Wiss 22:307-324 (in German)

Rötzler K (1995) Die P-T Entwicklung der Metamorphite des Mittelund Westerzgebirges. Sci. Techn. Rep., STR95/14, GeoForschungsZentrum Potsdam, Germany: p 220 (in German)

Rötzler K, Schumacher R, Maresch WV, Willner AP (1998) Characterization and geodynamic implications of contrasting metamorphic evolution in juxtaposed high-pressure units of the Western Erzgebirge (Saxony, Germany). Eur J Mineral 10:261-280

Rudnick RL, Gao S (2014) Composition of the continental crust. In: Holland HD, Turekian KK (eds) Treatise on geochemistry, 2nd edn. Elsevier, Amsterdam, pp 1-51

Sauer A (1887) Erläuterungen zur geologischen Specialkarte des Königreichs Sachsen, Section Freiberg: p 92 (in German)

Sauer A, Beck R (1891) Erläuterungen zur geologischen Specialkarte des Königreichs Sachsen, Section Tharandt: p 90 (in German)

Schmädicke E, Mezger K, Cosca MA, Okrusch M (1995) Variscan Sm$\mathrm{Nd}$ and $\mathrm{Ar}-\mathrm{Ar}$ ages of eclogite facies rocks from the Erzgebirge, Bohemian massif. J Metamorph Geol 13:537-552

Schmiedel T, Breitkreuz C, Görz I, Ehling BC (2015) Geometry of laccolith margins: 2D and 3D models of the Late Paleozoic Halle Volcanic Complex (Germany). Int J Earth Sci 104:323-333

Schoene B, Crowley JL, Condon DJ, Schmitz MD, Bowring SA (2006) Reassessing the uranium decay constants for geochronology using ID-TIMS U-Pb data. Geochim Cosmochim Acta 70:426-445

Schulze H (1963) Petrographisch-geochemische Untersuchungen der Tharandter Porphyre.- unpubl Diploma thesis Bergakademie Freiberg: p 88 (in German)

Schwab M (1962) Tektonische und vulkanotektonische Beobachtungen im Tharandter Wald (Sachsen).- - Halle Jb Mitteldeutsche Erdgeschichte 4: 69-81 (in German)

Sebastian U (2013) Die Geologie des Erzgebirges. Springer-Spektrum Verlag, Berlin, p 268 (in German)

Stanek K, Renno A (2001) Bericht zur Kartierung des Tharandter Vulkanit-Komplexes auf den Meßtischblättern (1:25000) Tharandt (5047) und Freiberg (5046).-unpubl. Rep. Landesamt Umwelt und Geologie, Freiberg, Germany, 1-82 (in German)

Štemprok M (1986) Petrology and geochemistry of the Czechoslovak part of the Krušné hory Mts. granite pluton. Sborník geol věd Ložisk geol Mineral 27:111-156

Thomas R (1994) Estimation of the viscosity and the water content of silicate melts from melt inclusion data. Eur J Mineral 6:511-535

Thomas R, Klemm W (1997) Microthermometric study of silicate melt inclusions in Variscan granites from SE Germany: volatile contents and entrapment conditions. J Petrol 38:1753-1765

Tichomirowa M (1997) ${ }^{207} \mathrm{~Pb} /{ }^{206} \mathrm{~Pb}$-Einzelzirkondatierungen zur Bestimmung des Intrusionsalters des Niederbobritzscher Granites. Terra Nostra 8:183-184 (in German)

Tichomirowa M, Berger HJ, Koch EA, Belyatski B, Götze J, Kempe U, Nasdala L, Schaltegger U (2001) Zircon ages of high-grade gneisses in the Eastern Erzgebirge (Central European Variscides)-constraints on origin of the rocks and Precambrian to Ordovician magmatic events in the Variscan foldbelt. Lithos 56:303-332

Tichomirowa M, Sergeev S, Berger HJ, Leonhardt D (2012) Inferring protoliths of high-grade metamorphic gneisses of the Erzgebirge using zirconology, geochemistry and comparison with lowergrade rocks from Lusatia (Saxothuringia, Germany). Contrib Mineral Petrol 164:375-396
Tichomirowa M, Käßner A, Sperner B, Lapp M, Leonhardt D, Linnemann U, Münker C, Ovtcharova M, Pfänder JA, Schaltegger U, Sergeev S, von Quadt A, Whitehouse M (2019) Dating multiply overprinted granites: the effect of protracted magmatism and fluid flow on dating systems (zircon U-Pb: SHRIMP/SIMS, LAICP-MS, CA-ID-TIMS; and Rb-Sr, Ar-Ar)—granites from the Western Erzgebirge (Bohemian Massif, Germany). Chem Geol 519:11-38

Tischendorf G, Geisler M, Gerstenberger H, Budzinski H, Vogler P (1987) Geochemistry of Variscan granites in the WesterzgebirgeVogtland region-an example of tin generating granites. Chem Erde 46:213-235

Tomek F, Žák J, Svojtka M, Finger F, Waitzinger M (2019) Emplacement dynamics of syn-collapse ring dikes: an example from the Altenberg-Teplice caldera, Bohemian Massif. Geol Soc Am Bull 131:997-1016

Tomek F, Opluštil S, Svojtka M, Špillar V, Rapprich V, Míková J (2021) Altenberg-Teplice Caldera sourced Westphalian fall tuffs in the central and western Bohemian Carboniferous basins (eastern Variscan belt). Int Geol Rev

Walker GPL (1984) Downsag calderas, ring faults, caldera sizes, and incremental caldera growth. J Geophys Res Solid Earth 89:8407-8416

Walker GPL (1985) Origin of coarse lithic breccias near ignimbrite source vents. J Volcanol Geotherm Res 25(1-2):157-171

Walther D, Breitkreuz C, Rapprich V, Kochergina Y, Chlupáčová M, Lapp M, Stanek K, Magna T (2016) The Late Carboniferous Schönfeld-Altenberg depression on the NW margin of the Bohemian Massif (Germany/Czech Republic): volcanosedimentary and magmatic evolution. J Geosci 61:371-393

Wetzel HU (1984) Spätvariszische Bruchtektonik und subsequente Gangmagmatite als Ausdruck der Krustenentwicklung im Osterzgebirge (Altenberger Scholle). Zentralinst. f. Physik d. Erde, Potsdam, Akad. d. Wiss. d. DDR, Potsdam unpubl PhD: p 364 (in German)

Wiedenbeck M, Alle P, Corfu F, Griffin WL, Meier M, Oberli F, von Quadt A, Roddick JC, Spiegel W (1995) Three natural zircon standards for $\mathrm{U}-\mathrm{Th}-\mathrm{Pb}, \mathrm{Lu}-\mathrm{Hf}$, trace element and REE analysis. Geostand Newsl 19:1-23

Willcock MAW, Cas RAF, Giordano G, Morelli C (2013) The eruption, pyroclastic flow behaviour, and caldera in-filling processes of the extremely large volume $\left(>1290 \mathrm{~km}^{3}\right)$, intra-to extra-caldera, Permian Ora (Ignimbrite) Formation, Southern Alps, Italy. J Volcanol Geotherm Res 265:102-126

Willner AP, Rötzler K, Maresch WV (1997) Pressure-temperature and fluid evolution of quartzo-feldspathic metamorphic rocks with a relic high-pressure, granulite-facies history from the Central Erzgebirge (Saxony, Germany). J Petrol 38:307-336

Willner AP, Krohe A, Maresch WV (2000) Interrelated P-T-t-d paths in the Variscan Erzgebirge dome (Saxony, Germany): constraints on the rapid exhumation of high-pressure rocks from the root zone of a collisional orogen. Int Geol Rev 42:64-85

Winter C, Breitkreuz C, Lapp M (2008) Textural analysis of a Late Palaeozoic coherent to pyroclastic rhyolitic dyke system near Burkersdorf (Erzgebirge, Saxony, Germany). Geol Soc Lond Spec Publ 302:197-219

Zieger J, Bittner L, Gärtner A, Hofmann M, Gerdes A, Marko L, Linnemann U (2019) U-Pb ages of magmatic and detrital zircon of the Döhlen Basin: geological history of a Permian strike-slip basin in the Elbe Zone (Germany). Int J Earth Sci 108:887-910 